
of Engineers ${ }_{\circledast}$

Engineer Research and

Development Center

\title{
Investigation of Lift Bonding for Roller- Compacted Concrete with Low Normal Loads at Variable Placement Times
}

Brett A. Williams, Brian H. Green, Rudolph A. Andreatta, Jason A. Morson, M. Kevin Taylor, Kirk E. Walker, Dan E. Wilson, and William S. Hart

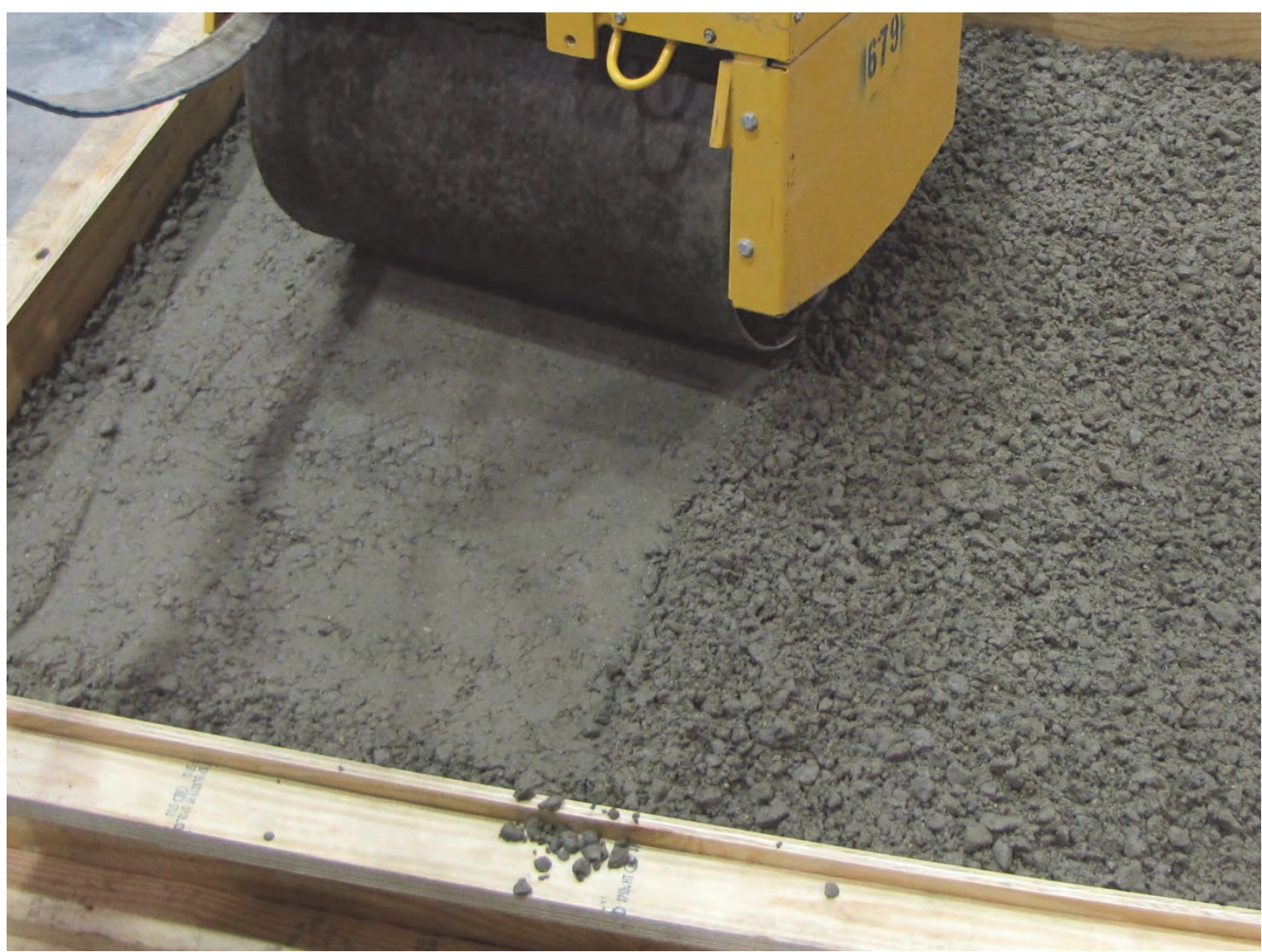


The US Army Engineer Research and Development Center (ERDC) solves the nation's toughest engineering and environmental challenges. ERDC develops innovative solutions in civil and military engineering, geospatial sciences, water resources, and environmental sciences for the Army, the Department of Defense, civilian agencies, and our nation's public good. Find out more at www.erdc.usace.army.mil.

To search for other technical reports published by ERDC, visit the ERDC online library at http://acwc.sdp.sirsi.net/client/default. 


\title{
Investigation of Lift Bonding for Roller- Compacted Concrete with Low Normal Loads at Variable Placement Times
}

\author{
Brett A. Williams, Brian H. Green, Rudolph A. Andreatta, \\ Jason A. Morson, M. Kevin Taylor, Kirk E. Walker, Dan E. Wilson, \\ and William S. Hart \\ Geotechnical and Structures Laboratory \\ US Army Engineer Research and Development Center \\ 3909 Halls Ferry Road \\ Vicksburg, MS 39180-6199
}

Final report

Approved for public release; distribution is unlimited.

$\begin{aligned} \text { Prepared for } & \text { US Army Corps of Engineers } \\ & \text { Washington, DC 20314-1000 } \\ \text { Under } & \text { Interagency Agreement 67-7482-9-494 - USACE RCC Structures }\end{aligned}$ 


\section{Abstract}

A problem arises when roller-compacted concrete (RCC) is placed in lifts where the normal loads at the lift-joint interface are relatively low. A study was conducted to investigate the effects of lapses of time between lifts on shear, tensile, and bond strengths of an RCC structure. Three test sections were constructed, each including two 6-in.-thick lifts, with the second lift placed at either 4, 13, or $24 \mathrm{hr}$ after the first lift was finished. Results of the study showed that if the second lift is placed within four hours of the first, the overall strength of the joint bond is increased. If the second lift is placed within $13 \mathrm{hr}$ of the first, the strength of the joint bond varies between increased and decreased strength throughout the surface area of the joint indicating signs of differential set times over the surface of the first lift. When the second lift is placed after $24 \mathrm{hr}$, the overall strength of the bond is decreased. These findings resulted from the execution of four different shear tests on each test section, where each shear test uniquely quantified the bond strength of the joint interface. The most adequate test method to quantify the shear strength of the bond was found to be the procedure in ASTM D 5607-08.

DISCLAIMER: The contents of this report are not to be used for advertising, publication, or promotional purposes. Citation of trade names does not constitute an official endorsement or approval of the use of such commercial products. All product names and trademarks cited are the property of their respective owners. The findings of this report are not to be construed as an official Department of the Army position unless so designated by other authorized documents. 


\section{Contents}

Abstract....................................................................................................................................... if

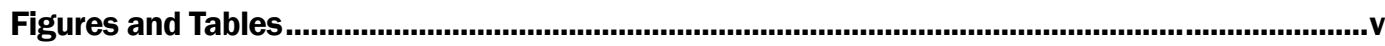

Preface ................................................................................................................................................vii

Unit Conversion Factors.........................................................................................................viif

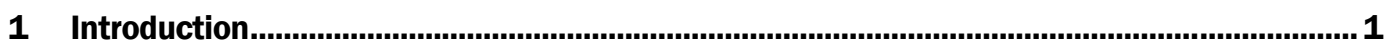

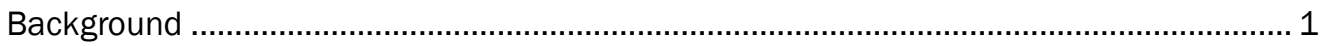

Purpose and scope ............................................................................................. 1

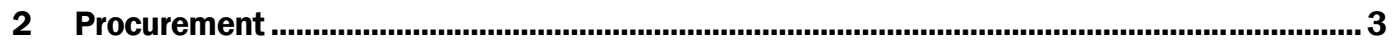

Test slab sizing and dimensions...................................................................... 3

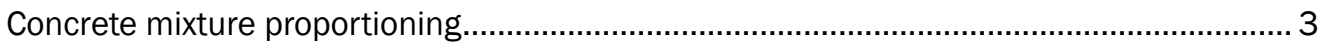

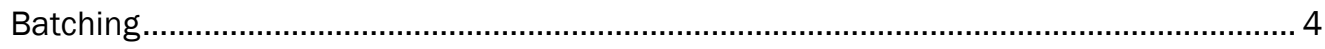

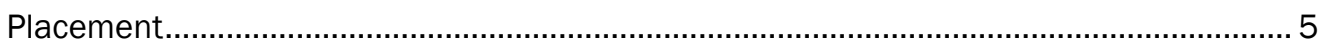

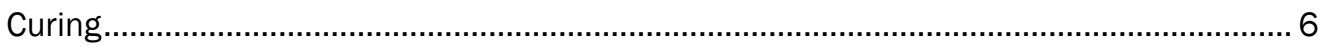

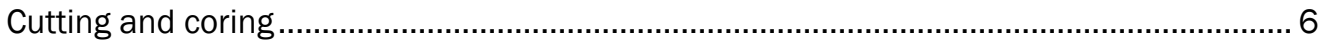

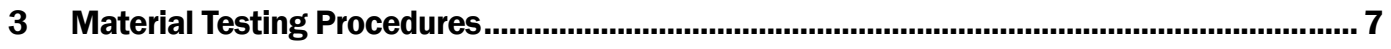

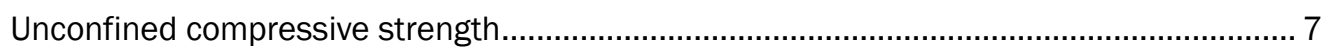

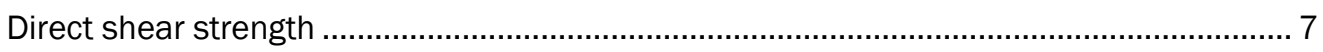

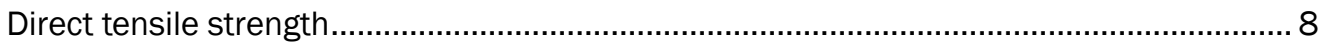

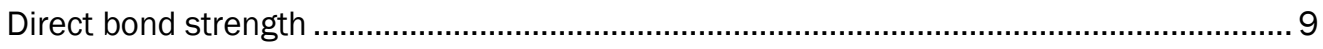

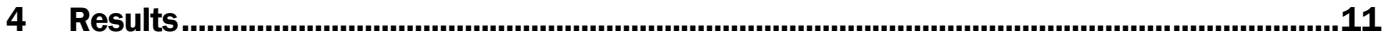

Batched material strength and density............................................................... 11

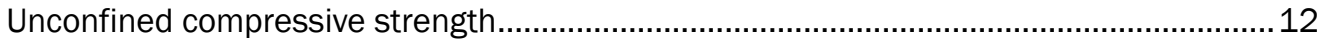

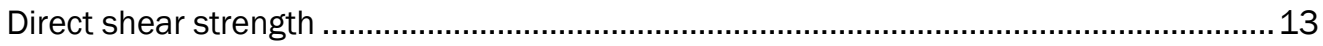

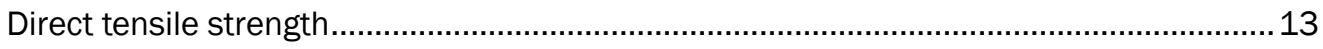

Direct bond strength ............................................................................................. 14

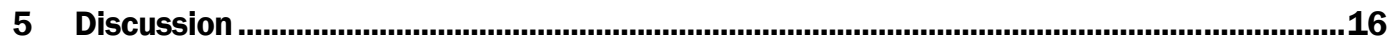

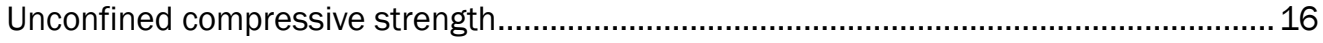

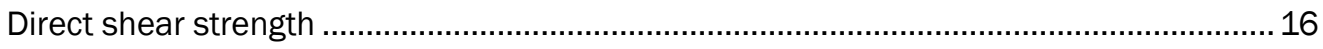

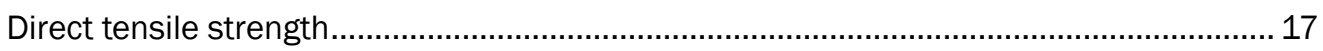

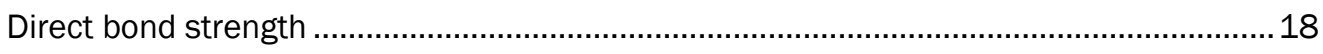

6 Conclusions and Recommendations ................................................................................19

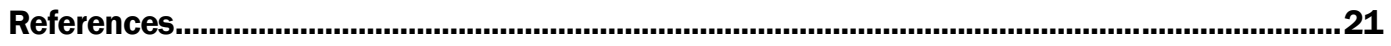

Appendix A: Detailed Results Tests Discussed in Chapter 4..................................................22 


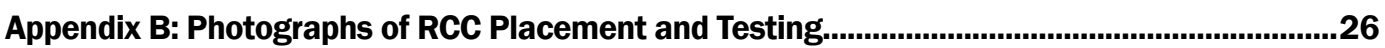

Appendix C: Investigation of Methods for Spreading Dry Cement Powder .

Report Documentation Page 


\section{Figures and Tables}

\section{Figures}

Figure 1. Compressive strength test specimen.......................................................................

Figure 2. Direct shear strength test specimen............................................................................... 8

Figure 3. Tensile strength test specimen.................................................................................. 9

Figure 4. Direct bond strength test specimen. .......................................................................... 10

Figure 5. Average unconfined compressive strengths of batched material.................................... 11

Figure 6. Unconfined compressive strength test results for all slab conditions. .............................. 12

Figure 7. Direct shear strengths for all slab conditions. Sample 4-6 and 8-9 were tested

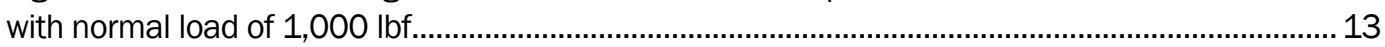

Figure 8. Direct tensile strength results for all slab conditions...................................................... 14

Figure 9. Bond strength test results for all slab conditions........................................................... 15

Figure B1. Vebe test being conducted prior to concrete placement. ..............................................26

Figure B2. First lift of concrete in forms prior to leveling and compaction. .....................................26

Figure B3. First lift of concrete being roller compacted................................................................. 27

Figure B4. Finished surface of first RCC lift.......................................................................... 27

Figure B5. Second lift of concrete in forms prior to leveling and compaction.................................. 28

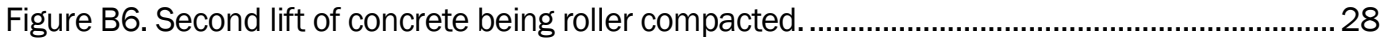

Figure B7. Close image of roller applying smooth surface ............................................................ 29

Figure B8. Cylinder being cast using the Vebe vibrating table.......................................................... 29

Figure B9. Final surface finish being applied via hand tamps...................................................... 30

Figure B10. Test slab being cut into specimens for shear testing and coring..................................30

Figure B11. Shear block being tested in loading frame. ..................................................................... 31

Figure B12. Concrete core in tension test machine. ……........................................................... 32

Figure B13. Concrete core after tension test was completed.........................................................32

Figure C1. Man-powered topping spreader: Designed by Tremix...................................................34

Figure C2. Manually pushed spreader bridge: Model designed by Alexey Gerasimchuck.................34

Figure C3. Mechanically operated spreader: Designed by Somero (Model STS-132

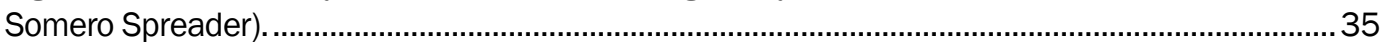

Figure C4. Tractor pulled cement spreader: Designed by Stoltz........................................................ 35

Figure C5. Operated vehicle cement spreader: Designed by Stoltz. …………………………….....36

Figure C6. Hand crank fertilizer spreader: Generic........................................................................36

Figure C7. Manually pushed fertilizer spreader: Designed by Spyker. ............................................... 37

Figure C8. Tractor-pulled lime/fertilizer spreader: Designed by Liberty Mechanical (Model

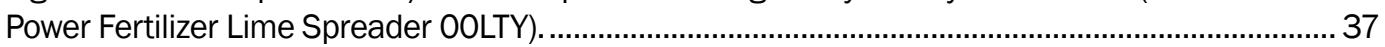

Figure C9. Truck-mounted aggregate spreader: Designed by BBI (Model RockBody OORB).............37 


\section{Tables}

Table 1. Mixture proportion for RC concrete............................................................................. 4

Table 2. Material properties for fine and coarse aggregates........................................................... 4

Table 3. Fresh properties of batched materials. ……………........................................................ 5

Table 4. Average densities of batched material cylinders............................................................... 12 


\section{Preface}

This research was conducted by personnel with the US Army Engineer Research and Development Center (ERDC) for Headquarters, US Army Corps of Engineers (USACE) under Interagency Agreement 67-7482-9494 with project title “USACE RCC Structures” and was funded by Natural Resource Conservation Service (NRCS).

Brian H. Green, Concrete and Materials Branch (CMB), Engineering Systems and Materials Division (ESMD), Geotechnical and Structures Laboratory (GSL), ERDC, was the Principal Investigator and project manager. Brett A. Williams (CMB) oversaw materials characterization to include mechanical testing and the determination of material properties. William S. Hart (CMB) contributed in construction, sample preparation and researching background information. Rudolph A. Andreatta, J ason A. Morson, M. Kevin Taylor, Kirk E. Walker and Dan E. Wilson, all of CMB, were the technicians that assisted in carrying out this work. Williams, Green, and Hart prepared this report.

Christopher M. Moore was Chief, CMB and monitored this investigation; Dr. Larry N. Lynch was Chief, ESMD; Dr. William P. Grogan was Deputy Director, GSL; and Dr. David W. Pittman was Director, GSL.

COL Kevin J . Wilson was Commander of ERDC. Dr. J effery P. Holland was Director. 


\section{Unit Conversion Factors}

\begin{tabular}{|l|c|l|}
\hline Multiply & By & To Obtain \\
\hline cubic feet & 0.02831685 & cubic meters \\
\hline cubic inches & $1.6387064 \mathrm{E}-05$ & cubic meters \\
\hline cubic yards & 0.7645549 & cubic meters \\
\hline degrees (angle) & 0.01745329 & radians \\
\hline degrees Fahrenheit & $($ F-32)/1.8 & degrees Celsius \\
\hline feet & 0.3048 & meters \\
\hline gallons (U.S. liquid) & $3.785412 \mathrm{E}-03$ & cubic meters \\
\hline inches & 0.0254 & meters \\
\hline pounds (force) & 4.448222 & newtons \\
\hline pounds (mass) & 0.45359237 & kilograms \\
\hline square feet & 0.09290304 & square meters \\
\hline square inches & $6.4516 \mathrm{E}-04$ & square meters \\
\hline square yards & 0.8361274 & square meters \\
\hline yards & 0.9144 & meters \\
\hline
\end{tabular}




\section{Introduction}

\section{Background}

The Natural Resource Conservation Service (NRCS) is currently exploring the possibility of capping numerous earthen dams under their purview using roller-compacted concrete (RCC) with the goal of strengthening the stability of the dams and making them less likely to fail. Normal loads on the joints between the lifts of RCC will be relatively low, which makes cohesion between lifts more important than other common RCC applications (Adbel-Halim et al. 1997). Years of experience showed that the bond strength between lifts of RCC can often be improved with the addition of some type of bonding material, although other factors such as the length of time between the application of the top lift (more accurately the maturity of the preceding layer of RCC) can also be important to the subsequent development of the bond strength between the two adjacent layers. Since continuous construction is not possible or economically feasible in all cases, it is important to know the duration of time that can pass between RCC lifts such that proper adhesion of the lifts still occurs.

\section{Purpose and scope}

The purpose of this US Army Engineer Research and Development (ERDC) project was to conduct a comparative investigation of the allowable duration of time that can occur between the placements of successive RCC lifts, particularly on structures with relatively low normal loads on the lift joint. The investigation focused on bond maturity between the lifts to establish a window of workability in which RCC lifts can be placed, and determining the best test methods for quality assurance on joint strength. The research and testing were conducted using three different slabs with same dimensions and lift thicknesses. Each of the three panels had variable successive lift placement times of 4,13 , and $24 \mathrm{hr}$. This range in placement times was selected to measure the variations of bond strength, shear strength, and tensile strength of the lift joints.

The goal was to understand what was occurring at the bond interface of RCC lifts after various durations of time passed after placement of a preceding lift. The major issue was discovering how much time could pass before no adhesion occurred between the lifts. Through this investigation, a 
test method will be determined that most accurately illustrates the true bond strength between lifts. For this study, the normal loads applied to the bonding interface were relatively low; therefore, minimal additional frictional forces were available to increase the shear resistance between the lifts. This decrease in shear resistance due to no applied normal load makes the bond formed between lifts much more critical. The objectives of this study are as follows:

1. Create multiple test slabs using an RCC material adequate to mimic field conditions.

2. Conduct multiple and different tests of samples taken from the slabs to determine bond strength and determine the most accurate testing method.

3. Develop a window of time between RCC placements in lifts so that adequate bonding occurs between the lifts. 


\section{Procurement}

\section{Test slab sizing and dimensions}

The placement and construction methods used to create the slabs for testing needed to mimic typical field conditions of a small-scale RCC placement. To meet this criteria, the dimensions of each of the three slabs were selected to be 8 - $\mathrm{ft}$ wide by 8 -ft long by the thickness of two 6 -in. lifts, totaling 12-in. in thickness. These dimensions provided sufficient surface area so that proper placement and compaction could be achieved.

\section{Concrete mixture proportioning}

In selecting the appropriate mixture proportion, NRCS Construction Specification 36 was used for guidance. Material Specification 524 (Aggregates for Roller-Compacted Concrete) was also used in selecting coarse aggregate. The coarse aggregate gradation, ASTM \#57, was selected, since most contractors choose an aggregate with a maximum size of $1.5 \mathrm{in}$. and a nominal maximum size of $1.0 \mathrm{in}$. Water content was selected so that the Vebe time was approximately $20 \mathrm{sec}$ with the water at an optimum level. The final mix aimed to have all Vebe time between 25 and 30 sec. Unified Facilities Guide Specifications (2009) was also consulted during mixture proportion efforts.

The concrete used for this project contained typical constituents found in most Portland cement concrete (PCC) mixtures. The concrete was composed of natural concrete sand, ASTM \#57 crushed limestone, Type I cement, Class F fly ash, and water. The mixture proportions for the selected RCC mixture are presented in Table 1 . The mixture proportion quantities are shown for surface saturated conditions and equate to $1 \mathrm{yd}^{3}$ of batched material. The concrete's target ratio of water to cementitious materials $(\mathrm{w} / \mathrm{cm}$ ) was 0.75 with a design strength of 3,000 psi. Table 2 lists the material properties for the coarse and fine aggregates that were chosen.

The mixture proportioning reflects one of the benefits of using RCC versus typical PCC and that is the low amount of cementitious materials needed to bind the material together. The amount of cement needed is equal to the amount needed to coat the surfaces of the fine and coarse aggregates. The compaction effort applied at the time of placement forces the aggregates close together and creates a cement-paste matrix. 
Table 1. Mixture proportion for RC concrete.

\begin{tabular}{|l|l|}
\hline Constituent & Mass in Pounds \\
\hline Water & 194 \\
\hline Cement & 184 \\
\hline Class F Fly Ash & 53 \\
\hline $\begin{array}{l}\text { ASTM \#57 Crushed Limestone } \\
\text { (Coarse Agg.) }\end{array}$ & 2,203 \\
\hline Concrete Sand (Fine Agg.) & 1,537 \\
\hline Air & 0 \\
\hline
\end{tabular}

Table 2. Material properties for fine and coarse aggregates.

\begin{tabular}{|l|l|l|}
\hline & Fine Aggregate & Coarse Aggregate \\
\hline Type & Natural Concrete Sand & ASTM \#57 Crushed Limestone \\
\hline Location & $\begin{array}{l}\text { Buford, Highway 27 Pit, } \\
\text { Vicksburg, MS }\end{array}$ & $\begin{array}{l}\text { Martin Marrietta, Vicksburg, MS } \\
\text { Yard }\end{array}$ \\
\hline Specific Gravity & 2.61 & 2.74 \\
\hline Absorption & 0.8 & 1 \\
\hline
\end{tabular}

\section{Batching}

The ERDC batching facility is a pug mill style mixer that uses two mixing shafts with attached angled fins to create a shearing and tumbling action to blend the concrete materials together. The maximum capacity of a single batch in this mixer is approximately $27 \mathrm{ft}^{3}$. The aggregates are dumped from hydraulically operated rectangular prism-shaped storage bins onto a conveyor equipped with a scale. Another conveyor system loads weighed material into the top of the mixer. Water is weighed and added via a storage tank mounted on top of the mixer. All batching and placing was completed in laboratory conditions at approximately $72^{\circ} \mathrm{F}$.

The material used for this project was batched using the same procedures for each lift for the three slabs. Most (90 percent) of the water was weighed first to remain in the storage tank until all of the dry materials were properly blended. The last 10 percent of water was held out so that adjustments could be made post-batching once fresh properties of the concrete were obtained. The concrete sand was weighed and distributed into the mixer. Following the concrete sand, the ASTM \#57 crushed limestone was weighed and added to the mixer. The two aggregates were then blended for approximately $5 \mathrm{~min}$, and then the Type I Portland cement and Class F fly ash were 
directly loaded into the mixer to blend with the other dry materials for an additional $5 \mathrm{~min}$. Once the dry materials were thoroughly blended together, the pre-measured quantity of water (90 percent of the estimated total) was added. The concrete was sufficiently mixed for 5 more minutes to ensure proper blending of all the materials.

After the material was batched, fresh properties were obtained using the ASTM C 1170-08 (ASTM 2010d) test method. This test method produces the duration of time that it takes a cement paste to form around a surcharge in a measured container of fresh concrete material placed on a vibrating table, also known as Vebe time (see Figures C1 and C8 in Appendix B). The target Vebe time for this mixture was between 25 and $30 \mathrm{sec}$. After each batch was prepared, an initial Vebe time was measured, and water was then added as needed to meet the target Vebe time. Table 3 shows the final Vebe times measured for all six batches (one batch per lift, two lifts per slab for three slabs) after all adjustments were made.

Table 3. Fresh properties of batched materials.

\begin{tabular}{|l|l|}
\hline Batch No. (Lift No. of Slab No.) & Final Vebe Time (seconds) \\
\hline No. 1 (1 of 1$)$ & 20 \\
\hline No. 2 (2 of 1$)$ & 27 \\
\hline No. 3 (1 of 2$)$ & 27 \\
\hline No. 4 (2 of 2$)$ & 28 \\
\hline No. 5 (1 of 3$)$ & 28 \\
\hline No. 6 (2 of 3$)$ & 25 \\
\hline
\end{tabular}

Time of set tests were not conducted due to the difficulties associated with wet sieving an RCC mixture.

\section{Placement}

After batching, the material was discharged into a hopper where it was transported by a forklift to the placement location. The concrete was dumped into the slab form to a height of approximately 8 to $9 \mathrm{in}$. The material was then raked and graded so that the entire surface of the lift was level. Once the surface was level, a steel-drum vibratory roller compactor was placed into the form on top of the concrete. The roller compactor had a 30-in.-diam steel drum that had an approximate weight of 1,100 lb and vibratory compactive force of approximately 3,730 lbf. The compactor was 
first rolled over the entire surface of the lift without vibration to initially compact the material and to prevent sliding and shoving. Final compaction was then applied using vibratory compactive effort until the entire surface of the lift was smooth. This completed the process of placing the first lift of RCC for each of the three slabs. The next lift was placed after the set duration of time had elapsed for each of three different conditions (i.e., after 4,13 , or $24 \mathrm{hr}$ ). This work was executed with no joint treatment other than insuring that the surface of the lower layer was clean and saturated, but surface dry. A control slab was not placed due to a lack of resources. Photographs of the placement and compaction processes are presented in Appendix B.

\section{Curing}

After each slab was completely cast, i.e., both lifts were placed, saturated burlap sheeting was placed over the entire surface. Plastic sheeting 6-mils thick was then placed to cover each slab along with a second layer of burlap to prevent moisture from escaping the surface of the slab. The slabs were allowed to cure for approximately 28 days. Periodically throughout the 28-day wet curing process, water was applied to the top burlap sheeting to maintain constant saturation. After all slabs had cured for 28 days, they were moved to a fogging chamber where perforated hoses were placed on the top surface of the three slabs so that water could leach constantly onto each slab. Each slab remained fully saturated for an additional 62 days so that the slabs went through a 90-day wet-curing process to allow for complete hydration.

\section{Cutting and coring}

After the slabs had cured, they were prepared to be cut and cored to obtain test cubes and cylinders. Each panel was cut into small cubes, approximately 12-in. by 12-in. by 12-in., and these cubes formed the blocks used for direct shear testing of each bond lift (see Figure B10 in Appendix B). Cylinders were cored from the slab at random locations throughout the slab so that the entire surface of the responses of the joint bond could be captured in each of the different tests. A tabletop core drill and 6-in. core barrel (having diamond impregnated crowned cutting segments) were used to core samples. 


\section{Material Testing Procedures}

For all tests described in this chapter, samples were taken at random from various locations in the slab. For each particular test method, samples were selected from both the edges and the middle of the parent slab.

\section{Unconfined compressive strength}

Compressive strength is important for ensuring that the concrete will not crush easily under the normal loads applied by multiple RCC lifts. All compressive strength testing was conducted in accordance with ASTM C 39-08 (ASTM 2010a) procedures. The concrete mixtures were evaluated using 6-in.-diam by 12-in.-high cylinders that were cored from the parent slabs. Results are reported as the maximum compressive stress obtained, which equals the maximum force recorded divided by the test sample's initial cross-sectional area. A compression test specimen is illustrated in Figure 1. Compressive tests on the parent material were only conducted on cast cylinders, whereas the compressive tests on the jointed materials were only conducted on cored cylinders.

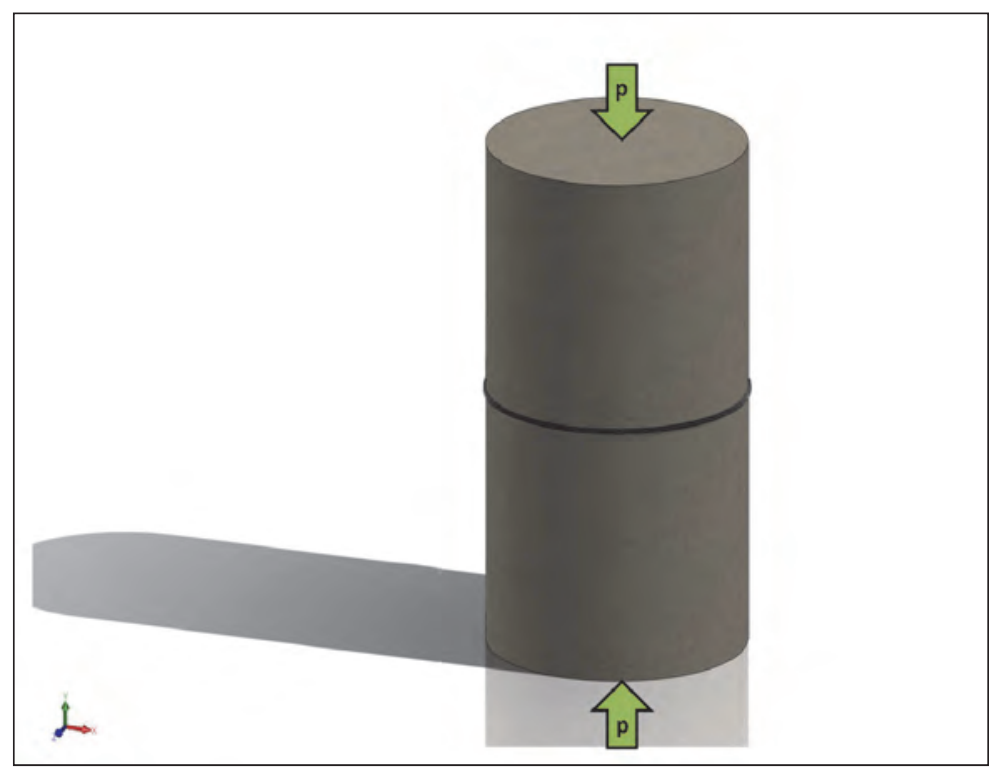

Figure 1. Compressive strength test specimen.

\section{Direct shear strength}

Shear tests are used to determine the load required for the upper lift of RCC to slip relative to the lower lift. All direct shear strength testing was 
conducted using ASTM D 5607-08 (ASTM 2010h) procedures as a guideline. Although this ASTM standard calls for cored specimens, a 12-in. by 12-in. by 12-in. cube was used to provide a better representation of the bonded surface (see Figure B11 in Appendix B). Results are reported as the maximum shear stress obtained, which equals the maximum shear force recorded, divided by the test sample's initial cross-sectional area along the lift line. A direct shear strength test specimen, including the method of confinement and loading, is illustrated in Figure 2. This shear apparatus was designed to restrain the bottom lift of the sample using steel plates and bolts while a load was applied to the top lift using a steel plate connected to a swivel. Shims were used to make fine tune adjustments based on where the lift joint was located on each individual specimen. These shims were placed so that the loading was perpendicular to and directly above the lift joint. Half of the samples were tested with a normal load of 1,000 lbf (dead weight) resulting in a normal stress of 6-7 psi. This method is preferred for relatively low normal loads as opposed to using a secondary actuator to apply a normal load which can cause difficulties in quantifying friction forces.

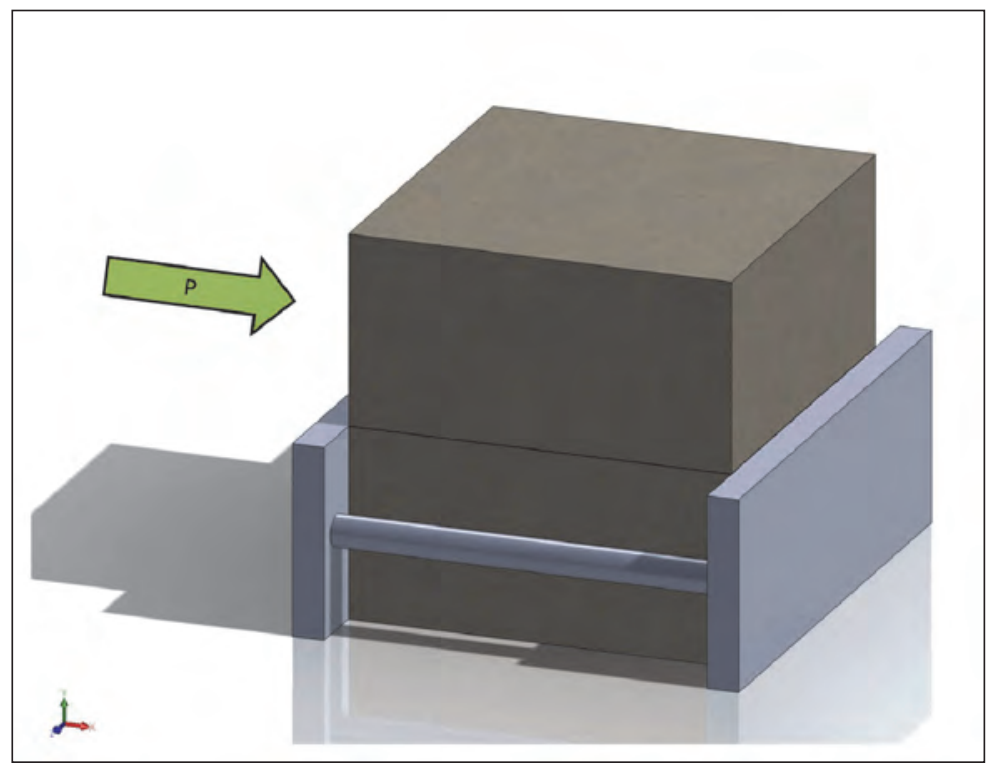

Figure 2. Direct shear strength test specimen.

\section{Direct tensile strength}

Tensile strength is the most direct method of determining bond strength between lifts of RCC. Each tension specimen was tested in accordance with ASTM D 2936-06 (ASTM 2008g) procedures. The concrete mixtures were evaluated using 6-in.-diam by 12-in.-high cylinders that were cored from 
parent slabs. Results are reported as the maximum tensile stress obtained, which equals the maximum force recorded divided by the test sample's initial cross-sectional area. Tension test samples were made by bonding steel plates to each end of 6-in.-diam by 12-in.-high cylinders as illustrated in Figure 3. The steel plates were attached to chains and then pulled in opposite directions in a universal testing machine (see Figures B12 and B13 in Appendix B).

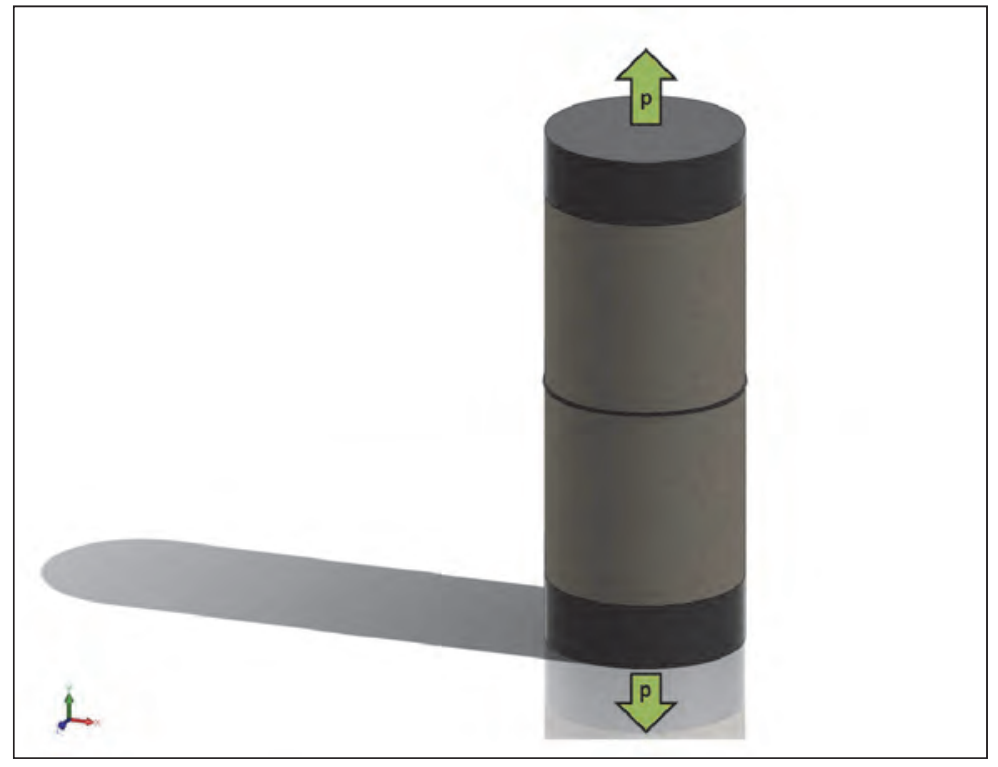

Figure 3. Tensile strength test specimen.

\section{Direct bond strength}

Bond strength is a standardized test that applies specifically to RCC. All bond strength testing was conducted in accordance with ASTM C 1245-08 (ASTM 2010f) procedures. The concrete mixtures were evaluated using 6-in.-diam by 12-in.-high cylinders that were cored from parent slabs. Results are reported as the maximum bond stress obtained, which equals the maximum force applied to the bond joint divided by the square of the specimen diameter at the bond surface. A bond strength test specimen is illustrated in Figure 4. 


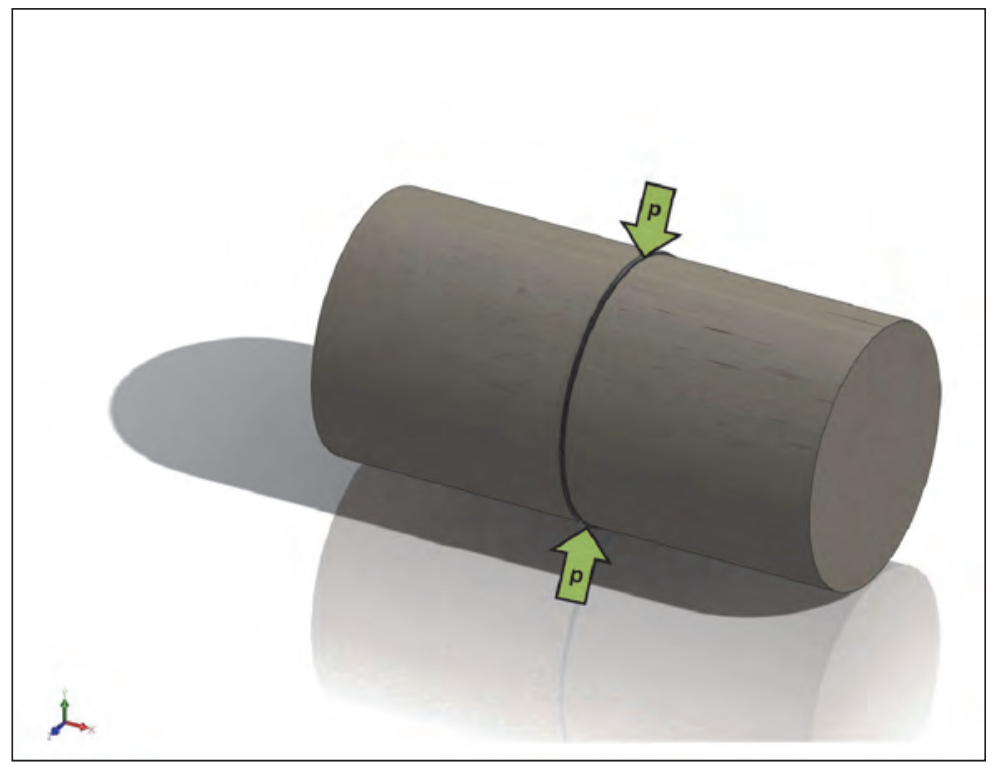

Figure 4. Direct bond strength test specimen. 


\section{Results}

\section{Batched material strength and density}

For each of the six batches that were placed, six test cylinders (6-in. diam by 12-in. high) were cast while the material was being placed using ASTM C 1176-08 (ASTM 2010e) procedures. Three cylinders each were tested at 28 days and 90 days for unconfined compressive strength of the concrete material itself (i.e., only the strength of the concrete not including the bond) in accordance with ASTM C 39-08 (ASTM 2010a) procedures. These strengths were compared to the strengths of the cored cylinders from the slabs that were cast. The average strengths of each of the six batches are illustrated in Figure 5. The average strength of all six batches combined was $2,922 \mathrm{psi}$ at 28 -days cure and 3,484 psi at 90-days cure.

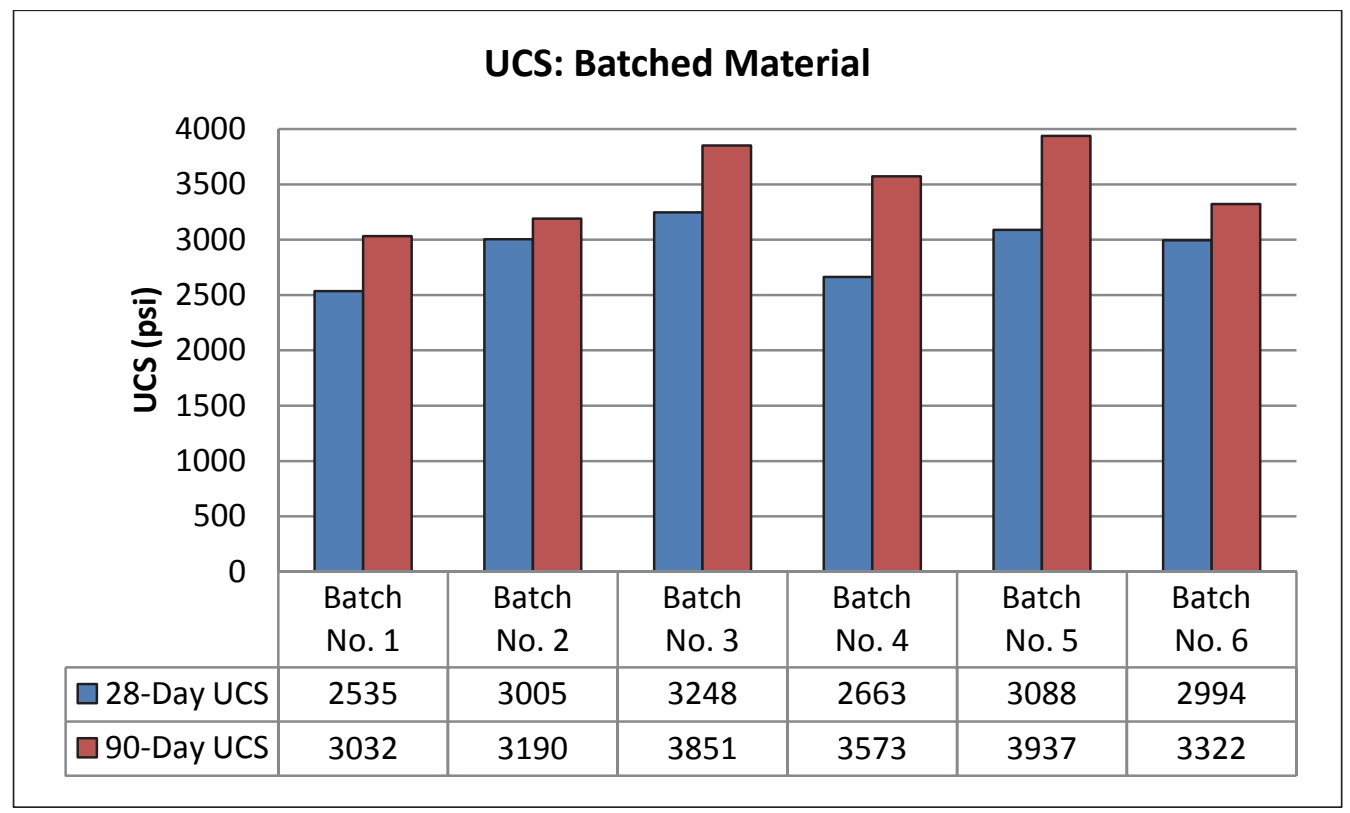

Figure 5. Average unconfined compressive strengths of batched material.

Densities were obtained from selected cylinders of each batch by measuring the mass of the cylinder in surface dry condition and when submerged in water. The procedures for determining the density of the hardened concrete was taken from ASTM C 642-06 (ASTM 2010c). The average density of all of the selected cylinders was $150 \mathrm{lb} / \mathrm{ft}^{3}$. Table 4 contains the actual average densities for each of the six different batches. 
Table 4. Average densities of batched material cylinders.

\begin{tabular}{|l|l|l|}
\hline Batch No. & $\begin{array}{l}\text { Lift No. of } \\
\text { Panel No. }\end{array}$ & $\begin{array}{l}\text { Density } \\
\text { (pcf) }\end{array}$ \\
\hline 1 & 1 of 1 & 151 \\
\hline 2 & 2 of 1 & 151 \\
\hline 3 & 1 of 2 & 149 \\
\hline 4 & 2 of 2 & 149 \\
\hline 5 & 1 of 3 & 148 \\
\hline 6 & 2 of 3 & 149 \\
\hline
\end{tabular}

\section{Unconfined compressive strength}

The unconfined compressive strength of the concrete in each of the three different slabs was determined from cored samples taken from random locations within each slab in accordance with ASTM C 42-10 (ASTM 2010b) and ASTM C 39-08 (ASTM 2010a) procedures. All cylinders for each of the three slab conditions were tested after the slabs had cured for 90 days. Three cylinders were tested for Slab Condition 1 with a resulting average unconfined compressive strength of 2,057 psi. Three cylinders were tested for Slab Condition 2 with a resulting average unconfined compressive strength of 2,350 psi. Four cylinders were tested for Slab Condition 3 with a resulting unconfined compressive strength of 2,624 psi. Figure 6 shows graphically the individual results for all three different slab conditions.

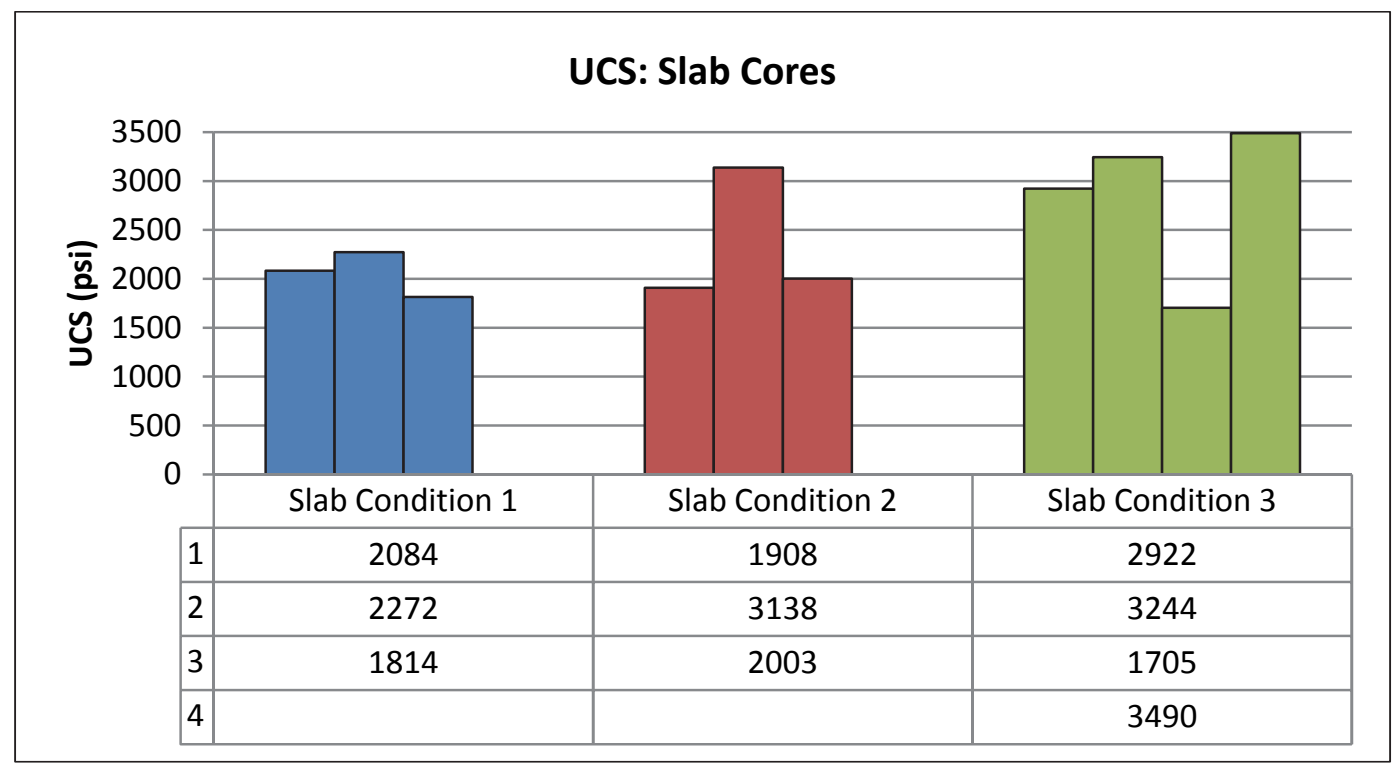

Figure 6. Unconfined compressive strength test results for all slab conditions. 


\section{Direct shear strength}

The shear strength of the joint bond was obtained using approximate square blocks directly cut from each of the three different slab conditions. These blocks were cut and tested after each of the slabs had cured for at least 90 days. The shear strength was calculated by taking the peak load directly applied to the joint bond and dividing it by the measured surface area of the bond plane. The results of the direct shear tests are plotted in Figure 7, which represents a scatter plot with connecting lines between data points. The data are represented in this manner to illustrate the variation in results for each specific slab condition and illustrate the comparison in results among the three conditions. The average direct shear strength of Slab Condition 1 was $197 \mathrm{psi}$ with a standard deviation of $46 \mathrm{psi}$. The average direct shear strength of Slab Condition 2 was 151 psi with a standard deviation of $87 \mathrm{psi}$ (note the high standard deviation). The average direct shear strength of Slab Condition 3 was 28 psi with a standard deviation of 9 psi. Samples 4-6 and 8-9 were tested with a normal load of 1,000 lbf resulting in a normal stress of approximately 6-7 psi. Considering the small sample size and variability from test to test, no conclusions could be made on the effect of normal loading conditions.

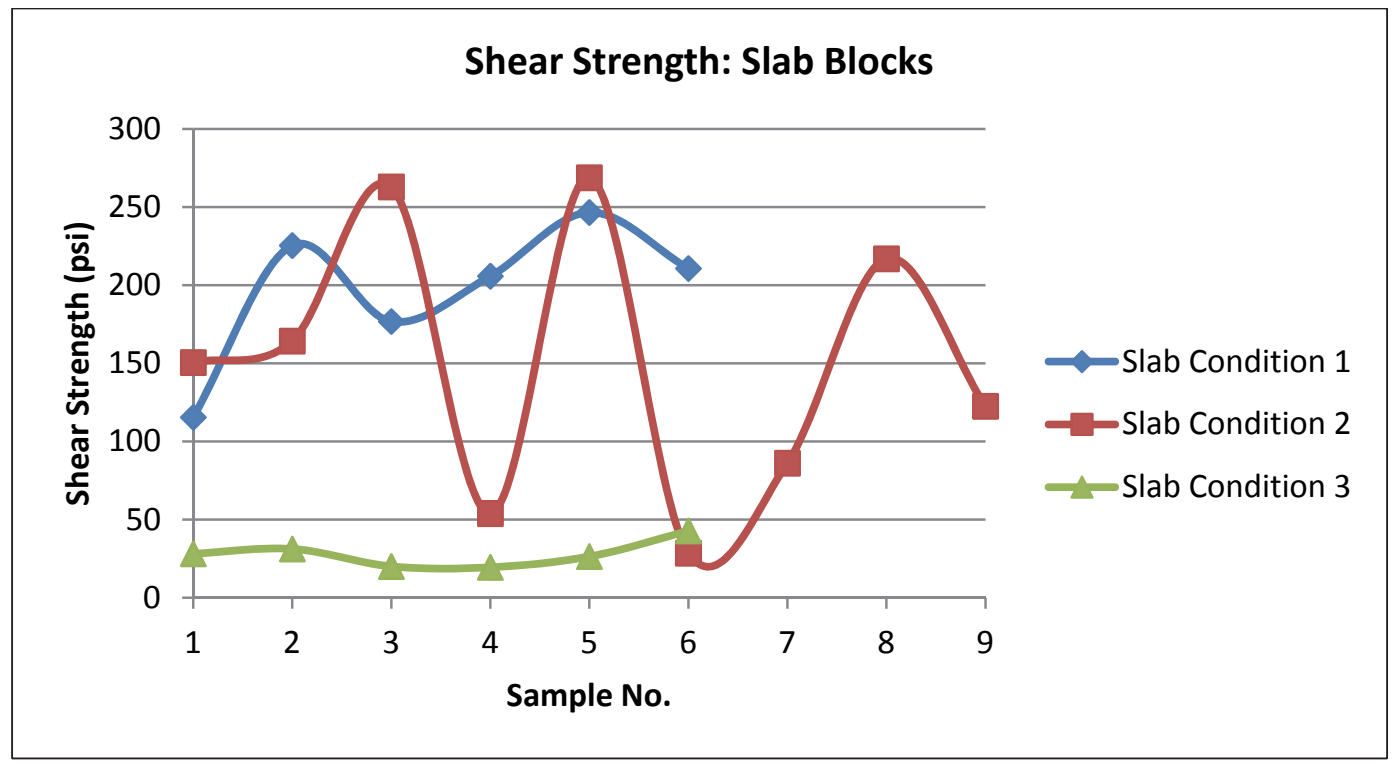

Figure 7. Direct shear strengths for all slab conditions. Sample 4-6 and 8-9 were tested with normal load of $1,000 \mathrm{lbf}$.

\section{Direct tensile strength}

The direct tensile strength of the joint bond was obtained using cored samples taken from the three different slab conditions in accordance with 
ASTM C 42-10 (ASTM 2010b) and ASTM D 2936-08 (ASTM 2010g) procedures. The cylinders were cut and prepared for testing after the slabs had cured for at least 90 days. This test applied direct tensile forces on the surface area of the lift joint bond. The direct tensile strength of the joint bond was calculated by dividing the peak load by the surface area of the cylinder at the joint bond plane. The results varied for the three different slab conditions as shown in Figure 8.

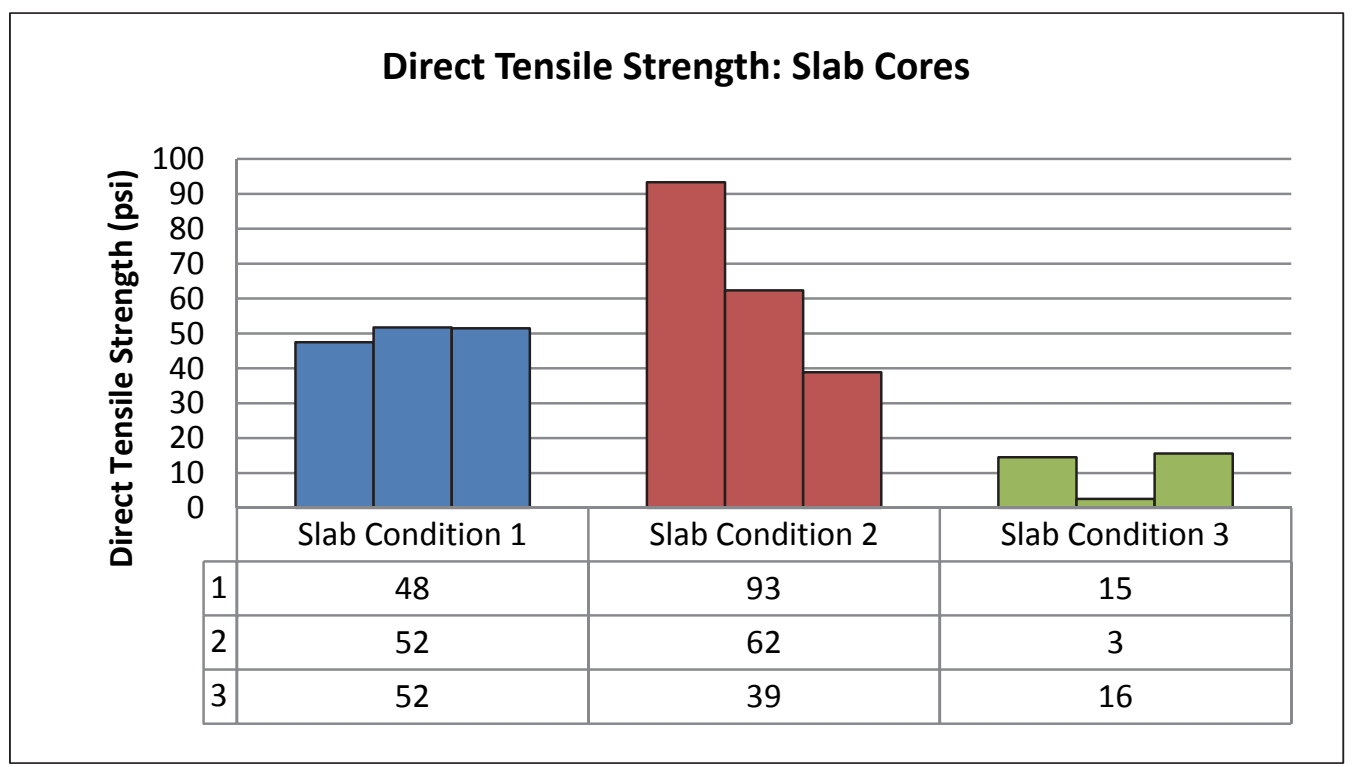

Figure 8. Direct tensile strength results for all slab conditions.

\section{Direct bond strength}

The direct bond strength of the three slab conditions was obtained using cored cylinders from the slabs after they had cured for at least 90 days. The bond strength was calculated using the procedures in ASTM C 124506 (ASTM 2010f), which is dividing the peak load applied to the bond plane by the average diameter of the cylinder squared. The results for the bond strength tests are in Figure 9. The average bond strengths were 65, 66, and 44 psi for slab conditions 1,2 , and 3 , respectively. The test results presented in Chapter 4 are presented in greater detail in Appendix A. 


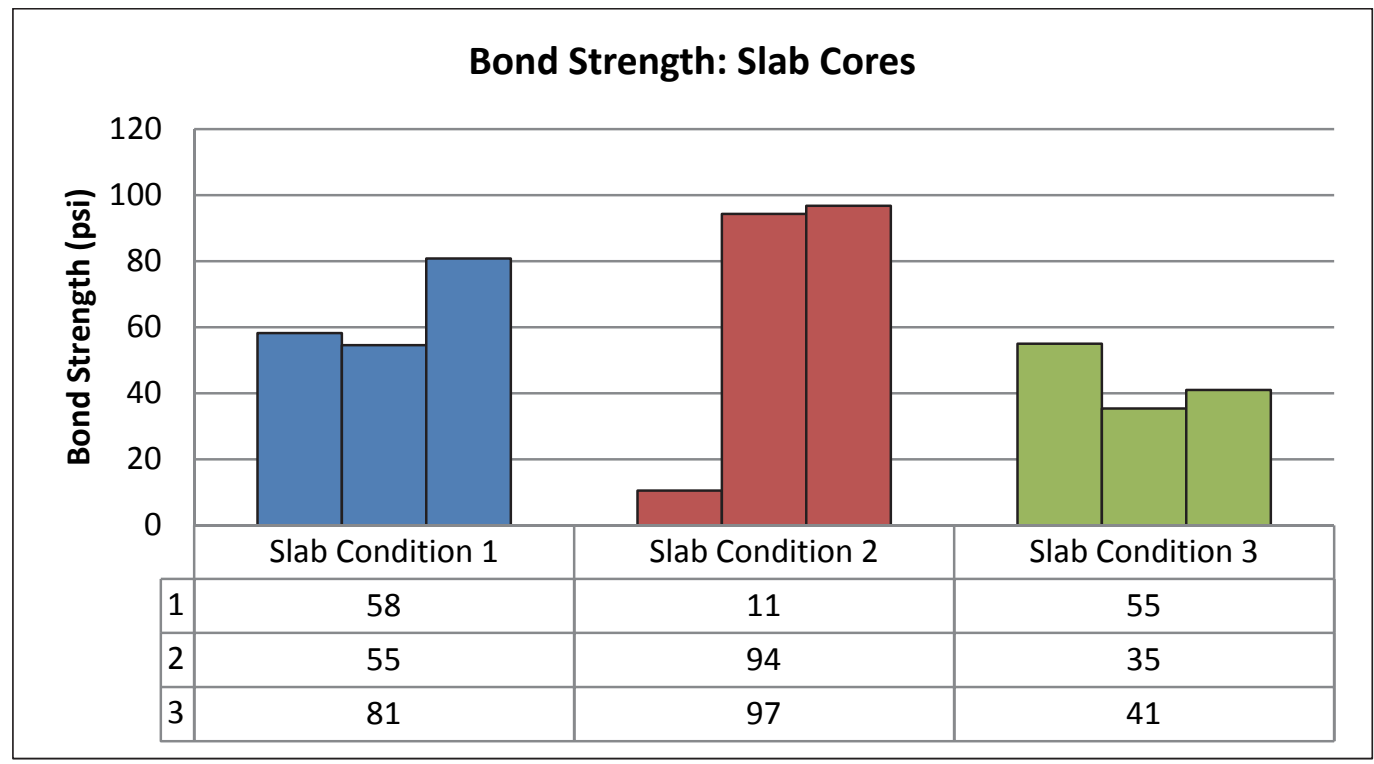

Figure 9. Bond strength test results for all slab conditions. 


\section{Discussion}

\section{Unconfined compressive strength}

The compressive strength of the cast samples verified that the design strength of 3,000 psi was achieved for all six batches after curing and aging for at least 90 days. Since each of the six batches exceeded the design strength, 3,000 psi will be used as the standard for comparing the compressive strengths of the cored specimens taken from each of the three slab conditions. The results of the compressive strengths for all three slab conditions demonstrated that the addition of a bonded layer within the tested cylinder caused the compressive strength to decrease. The average compressive strengths of Slab Conditions 1, 2, and 3 were approximately $1,000,700$, and 400 psi lower, respectively, than the standard. The elapsed time between lift placements did not seem to have an effect on the compressive strength since all three cases were lower than the target value of 3,000 psi. The range of compressive strengths between the three cases was $600 \mathrm{psi}$, which is an acceptable range when discussing compressive strengths of concrete cylinders.

The range of RCC densities was 140-160 lb/ $\mathrm{ft}^{3}$ depending mostly on the size of aggregate used and the compactive efforts applied during placement (US Army Corps of Engineers 2000). The average density of the concrete material used for this project was in the middle of that range at $150 \mathrm{lb} / \mathrm{ft}^{3}$. This verifies that the mixture proportioning of the concrete used in the slabs was sufficient to provide accurate results.

\section{Direct shear strength}

The direct shear results provided the primary finding from this research and illustrated exactly what was happening on the bond plane when each successive lift was placed. In the Slab Condition 1, the shear strength was comparatively high. The blocks that were tested were taken from random locations throughout the entire surface area of the slab. The bond between successive lifts for the edge and center were captured when the blocks were tested. The results from sample to sample were relatively consistent based on a standard deviation of only $46 \mathrm{psi}$ for six samples. These results reveal that the bond that formed between lifts was continuous throughout the entire surface area of the slab. For this slab condition, only $4 \mathrm{hr}$ had elapsed 
between slab placements, so the surface of the first lift had not reached initial set when the second lift was placed, and the cement paste from the two layers fused together. The results for Slab Condition 3 revealed that very little bond was formed between the first lift and the second lift, which was placed after $24 \mathrm{hr}$. The results were consistent based on a standard deviation of 9 psi for six samples. This revealed that the surface of the first lift had fully set and hydrated, and the only bond that formed was from the paste of the second lift. The results for Slab Condition 2 showed trends of the results for both Slab Conditions 1 and 3. Based on the results of six samples that were tested for Slab Condition 2, the data exhibited a large scatter, as shown in Figure 7. Although RCC shear data were typically presented in terms of cohesion and friction angle, these values were not reported, because only one normal loading condition was used.

At this stage, a hypothesis was formulated that, since the blocks that were tested were taken from different areas in the slab, some portions of Slab 2 were fully set, while other portions had not fully set at the time of placing the second lift. An additional three sample blocks for the Slab Condition 2 were tested in direct shear, and the hypothesis was verified when the variation in results mimicked the results found in the first six samples. These results indicated that for Slab Condition 2 after $13 \mathrm{hr}$ elapsed between lift placements, the surface of the first lift had both partially and fully set areas, which created an inconsistent bond when the second layer was placed. This inconsistency was illustrated by the large standard deviation of 87 psi obtained from the direct shear strengths for Slab Condition 2.

\section{Direct tensile strength}

The direct tensile test results support the findings from the direct shear tests for all three slab conditions. Slab Condition 1 averaged a direct tensile strength of 50 psi with a standard deviation of 2 psi. This reinforced the finding that the joint bond between the first and second lifts of an RCC placement was bonded together by the cement paste of the two lifts after $4 \mathrm{hr}$ had passed between lift placements. Slab Condition 2 averaged a direct tensile strength of $65 \mathrm{psi}$ but with a standard deviation of $27 \mathrm{psi}$. The high variability between the results supports the theory that certain surfaces of the first lift were setting and an insufficient bond was formed when $13 \mathrm{hr}$ of time had elapsed between placements. Slab Condition 3 averaged a direct tensile strength of $11 \mathrm{psi}$ with a standard deviation of $7 \mathrm{psi}$. These results are another illustration of how, after $24 \mathrm{hr}$ had passed between placement 
times, the only bond formed between lifts was from the cement paste supplied from the second lift.

\section{Direct bond strength}

Direct bond strength tests had the same pattern as those observed in the direct tensile strength tests. The bond strength test results also further support the primary findings from the direct shear tests in all three slab conditions. Slab Condition 1 tests revealed that the bond strengths from the three test cylinders were consistent suggesting that the second lift adhered to the first lift with the cement paste from both layers hydrating together since initial set of the first slab had not taken place. The tested cylinders cored from Slab Condition 2 revealed inconsistent bonding between the two lifts. This is another example of how the second lift was bonding inconsistently based on areas where the first lift either had or had not taken initial set. Slab Condition 3 showed very little bonding between the two lifts illustrating that the bottom lift had fully reached initial set, and the relatively weak resultant bond was from the cement paste of the second or top lift. 


\section{Conclusions and Recommendations}

The main purpose of this study was to evaluate the bond between two lifts of RCC when the second lift is placed 4, 13, and $24 \mathrm{hr}$ after the first lift. The tests to evaluate the bond of these three different conditions were compressive strength (ASTM C 39-08), direct shear (ASTM D 5607-08), direct tensile (ASTM D 2936-06), and bond strength (ASTM C 1245-08). The direct shear test results revealed the three primary findings of this research. The first finding is that, when $4 \mathrm{hr}$ passes in between placement of RCC lifts, the cement paste from both layers bond together and create a meshed interfacial bond plane that can withstand direct shear forces in excess of $197 \mathrm{psi}$. The second finding is that, when $24 \mathrm{hr}$ elapses between placements of RCC lifts, the surface of the first lift has fully set and hardened, and the only bond present is from the hydrating cement paste of the second lift. The bond between the two lifts can only withstand shear loads of $43 \mathrm{psi}$ at a maximum. The third finding is that, when $13 \mathrm{hr}$ passes in between placement of RCC lifts, the cement paste on the surface of the first layer is still setting in some portions of the slab's surface and has fully set in others. The discontinuity of the first lift's surface condition creates variable bonding ranging from the strong bond present in the 4-hr condition and the very weak bond in the 24-hr condition. The other strength tests performed support these findings for all three cases. It is important to note that these results are based having very low normal loads applied to the bond plane; therefore, the frictional forces between the two lifts add very little to the overall shear strength, or resistance to shear, of the bond.

It is recommended that, when placing lifts using the RCC method, a second lift should be placed at no more than $4 \mathrm{hr}$ after a preceding lift is placed. This would ensure that a bond would form between the cement pastes of both lifts and significantly increase the shear strength of the joint.

If it is not economically or physically feasible to place lifts within this time window, it is recommended that a supplementing bonding agent be applied to the lift joints (faces) to ensure that an adequate shear strength and bond between the lifts is present. One option is to spread cement powder on top of the previous lift prior to placing an additional lift. Options for spreading cement are discussed in great detail in Appendix C. Another example of a 
bonding agent is placing a grout with very low viscosity so that the paste of the grout can permeate through the dry, hardened surface of the bottom layer and bond with the hydrating cement of the top layer. An epoxy is another form of a bonding agent that could be applied to lift joints to increase the bond and raise the shear strength. When testing the bond between lifts, a direct shear test using ASTM D 5607-08 procedures as a guideline should be used. This test most accurately quantifies the resistance to shear of the bond formed between the lifts. Further studies may show that the ASTM D 5607-08 could be modified to use cored specimens versus blocks to make the test much easier to conduct. 


\section{References}

American Society for Testing and Materials. 2010. Annual Book of ASTM Standards 2008. Philadelphia, PA: American Society for Testing and Materials.

2010a. Designation C 39-08. Standard test method for compressive strength of concrete specimens. Philadelphia, PA: American Society for Testing and Materials.

2010b. Designation C 42-10. Standard Test Method for Obtaining and Testing Drilled Cores and Sawed Beams of Concrete. Philadelphia, PA: American Society for Testing and Materials.

2010c. Designation C 642-06. Philadelphia, PA: American Society for Testing and Materials.

2010d. Designation C 1170-08. Standard Test Method for Determining Consistency and Density of Roller-Compacted Concrete Using a Vibrating Table. Philadelphia, PA: American Society for Testing and Materials.

2010e. Designation C 1176-08. Standard Practice for Making Roller-Compacted Concrete in Cylinder Molds Using a Vibrating Table. Philadelphia, PA: American Society for Testing and Materials.

2010f. Designation C 1245-08. Standard Test Method for Determining Relative Bond Strength Between Hardened Roller Compacted Concrete Lifts (Point Load Test). Philadelphia, PA: American Society for Testing and Materials.

2010g. Designation D 2936-06. Standard Test Method for Direct Tensile Strength of Intact Rock Core Specimens. Philadelphia, PA: American Society for Testing and Materials.

2010h. Designation D 5607-08. Standard Test Method for Performing Laboratory Direct Shear Strength Tests of Rock Specimens Under Constant Normal Force. Philadelphia, PA: American Society for Testing and Materials.

Abdel-Halim, M. A. H., M. A. Al-Omari, M. M. Iskender. 1997. Rehabilitation of the spillway of Sama El-Serhan Dam in J ordan, using roller compacted concrete. Elservier Engineering Structures (21):497-506.

Headquarters, US Army Corps of Engineers. 2009. Unified Facilities Guide Specifications. UFGS-03 37 23. Roller-Compacted Concrete for Mass Concrete Constructions. Washington, DC: Headquarters, USACE.

Headquarters, US Army Corps of Engineers. 2000. Roller-Compacted Concrete, Engineer Manual 1110-2-2006. Engineering and Design. Washington, DC: U.S. Army Corps of Engineers. 


\section{Appendix A: Detailed Results Tests Discussed in Chapter 4}




\begin{tabular}{|c|c|c|c|c|c|c|c|c|c|}
\hline \multicolumn{10}{|c|}{ Shear Test (Approx. 12" x 12" Blocks) Results } \\
\hline $\begin{array}{l}\text { Slab } \\
\text { Placement } \\
\text { Condition }\end{array}$ & Sample No. & $\begin{array}{l}\text { Sample } \\
\text { Location }\end{array}$ & $\begin{array}{l}\text { Normal } \\
\text { Load (Ib) }\end{array}$ & $\begin{array}{l}\text { Sample } \\
\text { Dimension } \\
\text { (Length, in.) }\end{array}$ & $\begin{array}{l}\text { Sample } \\
\text { Dimension } \\
\text { (Width, in.) }\end{array}$ & Load (Ibf) & $\begin{array}{l}\text { Surface } \\
\text { Area }\left(\text { in }^{2}\right)\end{array}$ & $\begin{array}{l}\text { Shear } \\
\text { Strength } \\
\text { (psi) }\end{array}$ & Average \\
\hline \multirow{6}{*}{ 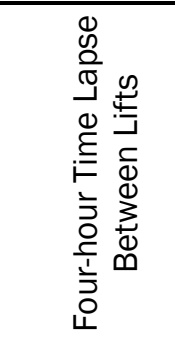 } & 1 & Center & 0 & 11.750 & 12.750 & 17,300 & 149.8 & 115 & \multirow{6}{*}{197} \\
\hline & 2 & Center & 0 & 13.125 & 13.500 & 39,947 & 177.2 & 225 & \\
\hline & 3 & Edge & 0 & 12.625 & 13.125 & 29,300 & 165.7 & 177 & \\
\hline & 4 & Center & 1000 & 13.000 & 12.875 & 34,449 & 167.4 & 206 & \\
\hline & 5 & Center & 1000 & 12.625 & 12.500 & 38,916 & 157.8 & 247 & \\
\hline & 6 & Edge & 1000 & 13.000 & 12.250 & 33,562 & 159.3 & 211 & \\
\hline \multirow{9}{*}{ 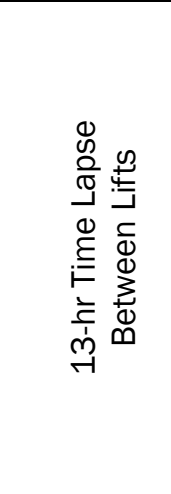 } & 1 & Center & 0 & 12.250 & 12.875 & 23,744 & 157.7 & 151 & \multirow{9}{*}{151} \\
\hline & 2 & Edge & 0 & 12.125 & 12.875 & 25,642 & 156.1 & 164 & \\
\hline & 3 & Edge & 0 & 13.125 & 12.250 & 42,287 & 160.8 & 263 & \\
\hline & 4 & Center & 1000 & 12.375 & 12.375 & 8,260 & 153.1 & 54 & \\
\hline & 5 & Center & 1000 & 12.125 & 12.250 & 39,930 & 148.5 & 269 & \\
\hline & 6 & Edge & 1000 & 12.375 & 12.250 & 4,321 & 151.6 & 29 & \\
\hline & 7 & Center & 0 & 12.500 & 12.500 & 13,460 & 156.3 & 86 & \\
\hline & 8 & Center & 1000 & 13.375 & 12.125 & 35,180 & 162.2 & 217 & \\
\hline & 9 & Center & 1000 & 12.375 & 13.000 & 19,714 & 160.9 & 123 & \\
\hline \multirow{6}{*}{ 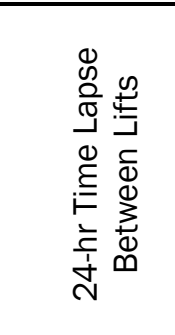 } & 1 & Center & 0 & 13.375 & 12.500 & 4,708 & 167.2 & 28 & \multirow{6}{*}{28} \\
\hline & 2 & Center & 0 & 12.875 & 12.875 & 5,182 & 165.8 & 31 & \\
\hline & 3 & Edge & 0 & 12.375 & 12.625 & 3,132 & 156.2 & 20 & \\
\hline & 4 & Center & 1000 & 12.500 & 12.500 & 3,043 & 156.3 & 19 & \\
\hline & 5 & Edge & 1000 & 11.625 & 12.500 & 3,830 & 145.3 & 26 & \\
\hline & 6 & Center & 1000 & 12.625 & 12.750 & 6,886 & 161.0 & 43 & \\
\hline
\end{tabular}




\begin{tabular}{|c|c|c|c|c|c|c|c|c|}
\hline \multicolumn{9}{|c|}{ Cored 6" x 12" Cylinder Test Results } \\
\hline $\begin{array}{l}\text { Slab } \\
\text { Placement } \\
\text { Condition }\end{array}$ & $\begin{array}{l}\text { Sample } \\
\text { No. }\end{array}$ & $\begin{array}{l}\text { Compressive } \\
\text { Strength (psi) }\end{array}$ & $\begin{array}{l}\text { Average } \\
\text { Compressive } \\
\text { Strength (psi) }\end{array}$ & $\begin{array}{l}\text { Direct Tensile } \\
\text { Strength (psi) }\end{array}$ & $\begin{array}{l}\text { Average Direct } \\
\text { Tensile Strength } \\
\text { (psi) }\end{array}$ & $\begin{array}{l}\text { Bond } \\
\text { Strength } \\
\text { (lbf) }\end{array}$ & $\begin{array}{l}\text { Bond } \\
\text { Strength } \\
\text { (psi) }\end{array}$ & $\begin{array}{l}\text { Average Bond } \\
\text { Strength (psi) }\end{array}$ \\
\hline \multirow{4}{*}{ 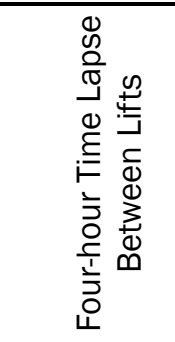 } & 1 & 2,084 & \multirow{3}{*}{2,057} & 48 & \multirow{3}{*}{50} & 2,098 & 58 & \multirow{3}{*}{65} \\
\hline & 2 & 2,272 & & 52 & & 1,965 & 55 & \\
\hline & 3 & 1,814 & & 52 & & 2,909 & 81 & \\
\hline & & & & & & & & \\
\hline \multirow{4}{*}{ 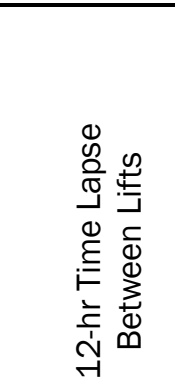 } & 1 & 1,908 & \multirow{3}{*}{2,350} & 93 & \multirow{3}{*}{65} & 380 & 11 & \multirow{3}{*}{67} \\
\hline & 2 & 3,138 & & 62 & & 3,395 & 94 & \\
\hline & 3 & 2,003 & & 39 & & 3,484 & 97 & \\
\hline & & & & & & & & \\
\hline \multirow{4}{*}{ 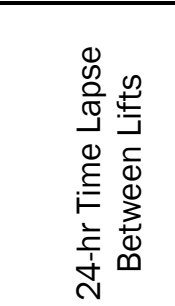 } & 1 & 2,922 & \multirow{4}{*}{2,624} & 15 & \multirow{3}{*}{11} & 1,981 & 55 & \multirow{3}{*}{44} \\
\hline & 2 & 3,244 & & 3 & & 1,274 & 35 & \\
\hline & 3 & 1,705 & & 16 & & 1,476 & 41 & \\
\hline & 4 & 3,490 & & & & & & \\
\hline
\end{tabular}




\begin{tabular}{|c|c|c|c|c|c|}
\hline \multicolumn{6}{|c|}{ Compressive Strength Test Results } \\
\hline $\begin{array}{l}\text { Batch } \\
\text { No. }\end{array}$ & $\begin{array}{l}\text { Lift No. of } \\
\text { Panel No. }\end{array}$ & $\begin{array}{l}\text { Sample } \\
\text { No. }\end{array}$ & $\begin{array}{l}\text { 28-Day } \\
\text { UCS (psi) }\end{array}$ & $\begin{array}{l}\text { 90-Day UCS } \\
\text { (psi) }\end{array}$ & $\begin{array}{l}\text { Density } \\
\text { (lb/cu ft) }\end{array}$ \\
\hline \multirow{6}{*}{1} & \multirow{6}{*}{1 of 1} & 1 & 2,595 & & \\
\hline & & 2 & 2,697 & & \\
\hline & & 3 & 2,314 & & \\
\hline & & 4 & & 3,476 & 151.3 \\
\hline & & 5 & & 2,497 & 150.6 \\
\hline & & 6 & & 3,122 & 150.6 \\
\hline \multirow{6}{*}{2} & \multirow{6}{*}{2 of 1} & 7 & 2,895 & & \\
\hline & & 8 & 3,046 & & \\
\hline & & 9 & 3,073 & & \\
\hline & & 10 & & 3,777 & 152.1 \\
\hline & & 11 & & 3,813 & 151.6 \\
\hline & & 12 & & 1,981 & 149.7 \\
\hline \multirow{6}{*}{3} & \multirow{6}{*}{1 of 2} & 1 & 3,079 & & \\
\hline & & 2 & 3,450 & & \\
\hline & & 3 & 3,214 & & \\
\hline & & 4 & & 3,625 & 149.4 \\
\hline & & 5 & & 4,048 & 149.7 \\
\hline & & 6 & & 3,881 & 149.1 \\
\hline \multirow{6}{*}{4} & \multirow{6}{*}{2 of 2} & 7 & 3,107 & & \\
\hline & & 8 & 2,335 & & \\
\hline & & 9 & 2,548 & & \\
\hline & & 10 & & 3,578 & 149.5 \\
\hline & & 11 & & 3,345 & 148.7 \\
\hline & & 12 & & 3,796 & 150.2 \\
\hline \multirow{6}{*}{5} & \multirow{6}{*}{1 of 3} & 1 & 2,744 & & \\
\hline & & 2 & 3,228 & & \\
\hline & & 3 & 3,293 & & \\
\hline & & 4 & & 3,894 & 148.7 \\
\hline & & 5 & & 4,022 & 148.6 \\
\hline & & 6 & & 3,895 & 147.8 \\
\hline \multirow{6}{*}{6} & \multirow{6}{*}{2 of 3} & 7 & 3,059 & & \\
\hline & & 8 & 3,117 & & \\
\hline & & 9 & 2,807 & & \\
\hline & & 10 & & 3,210 & 148.7 \\
\hline & & 11 & & 3,463 & 148.7 \\
\hline & & 12 & & 3,294 & 148.5 \\
\hline
\end{tabular}




\section{Appendix B: Photographs of RCC Placement and Testing}

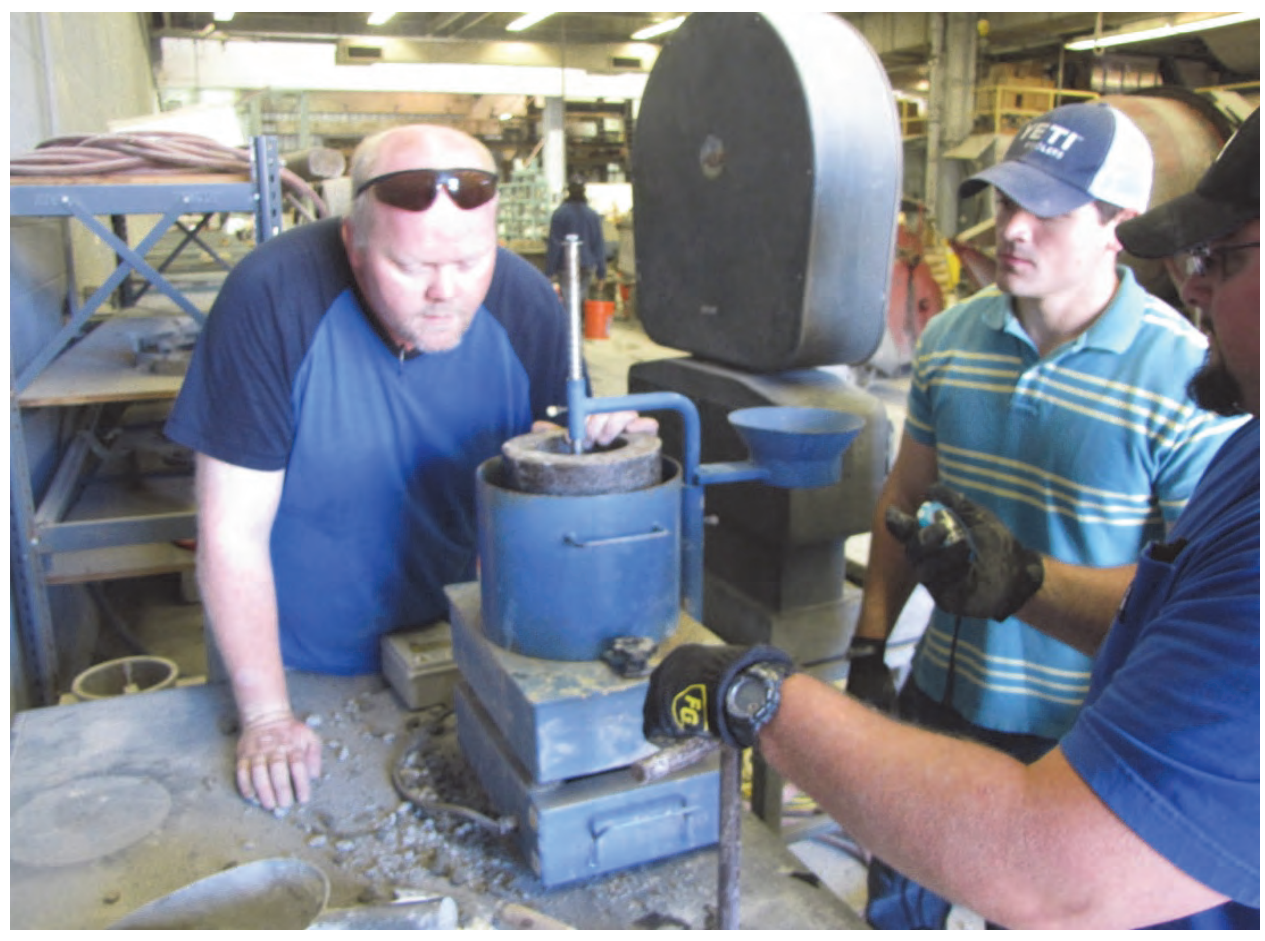

Figure B1. Vebe test being conducted prior to concrete placement.

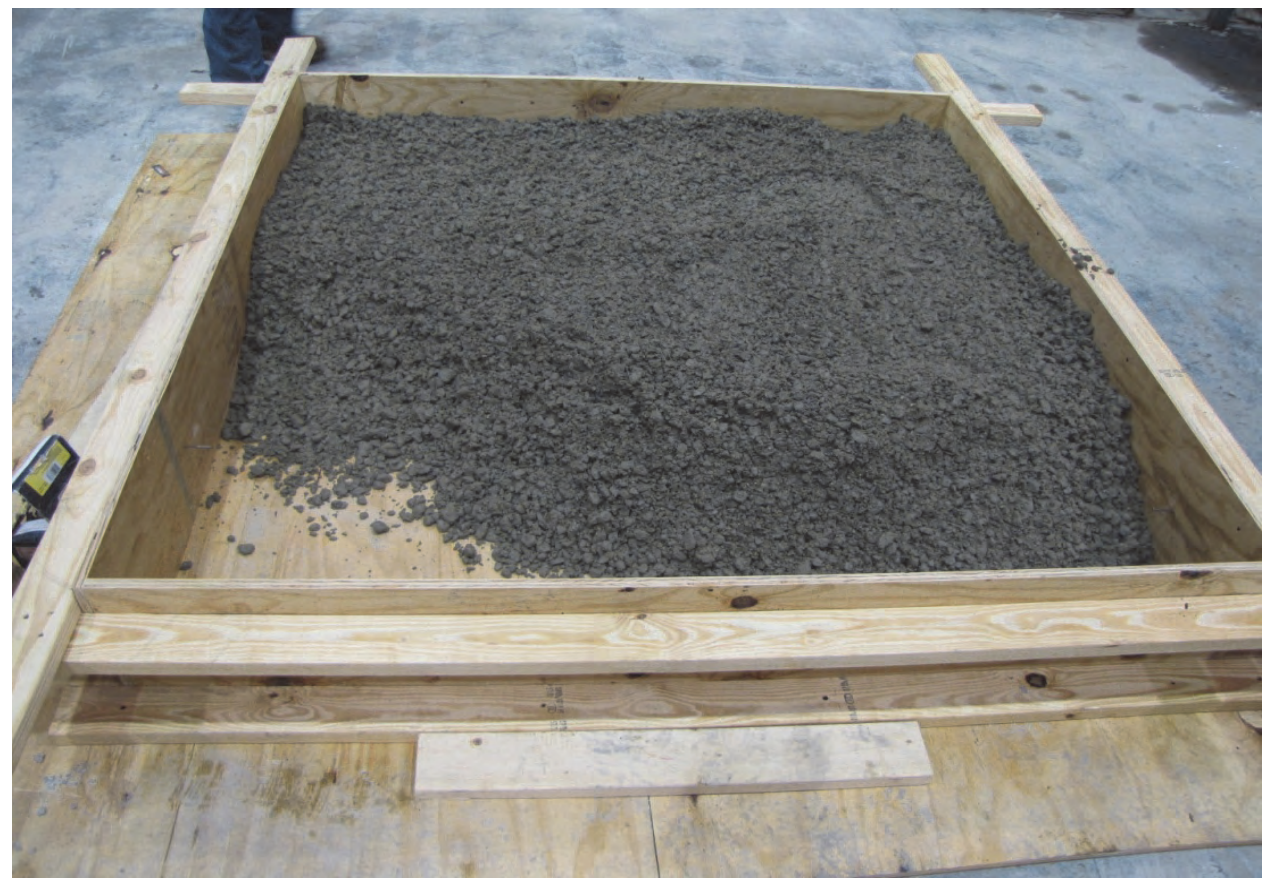

Figure B2. First lift of concrete in forms prior to leveling and compaction. 


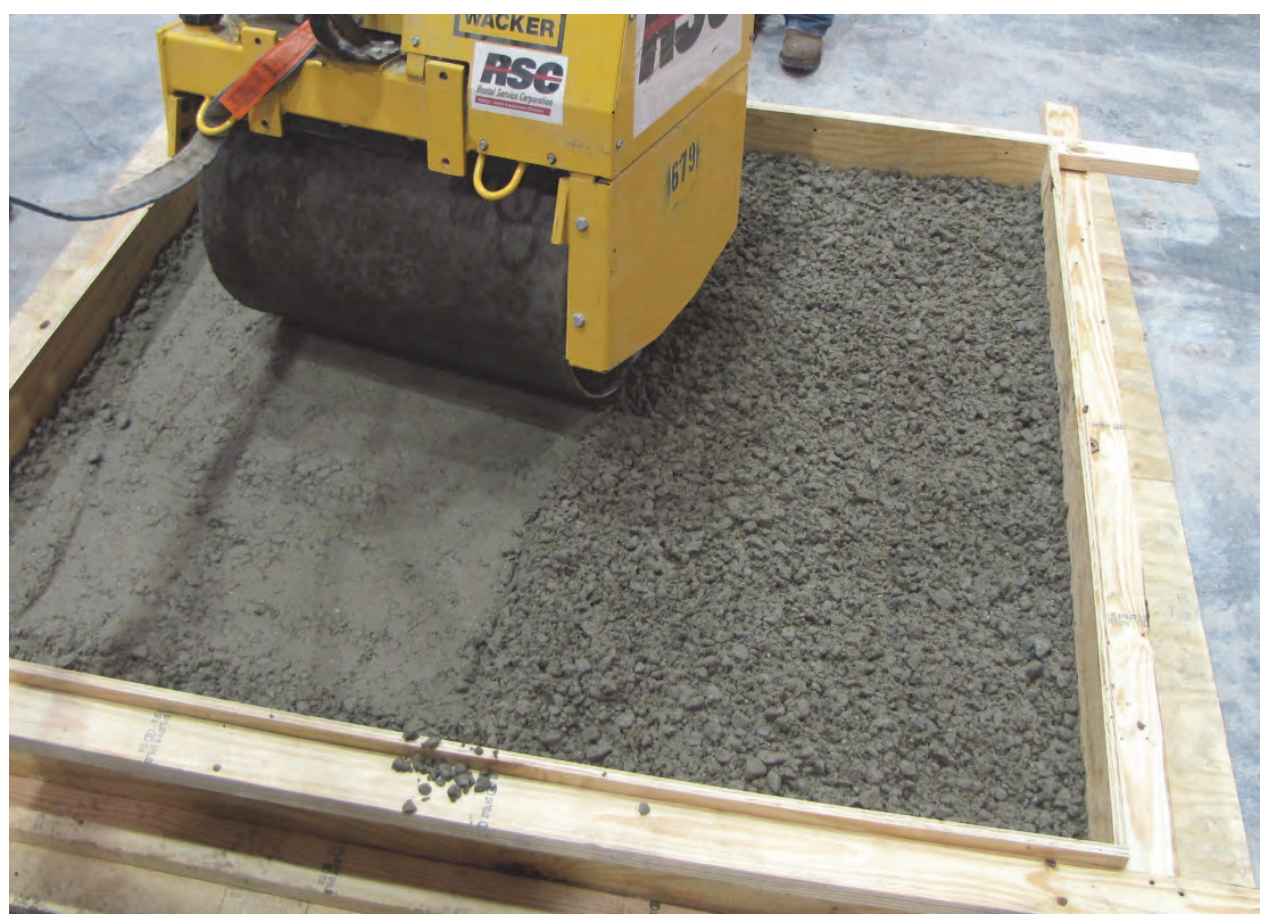

Figure B3. First lift of concrete being roller compacted.

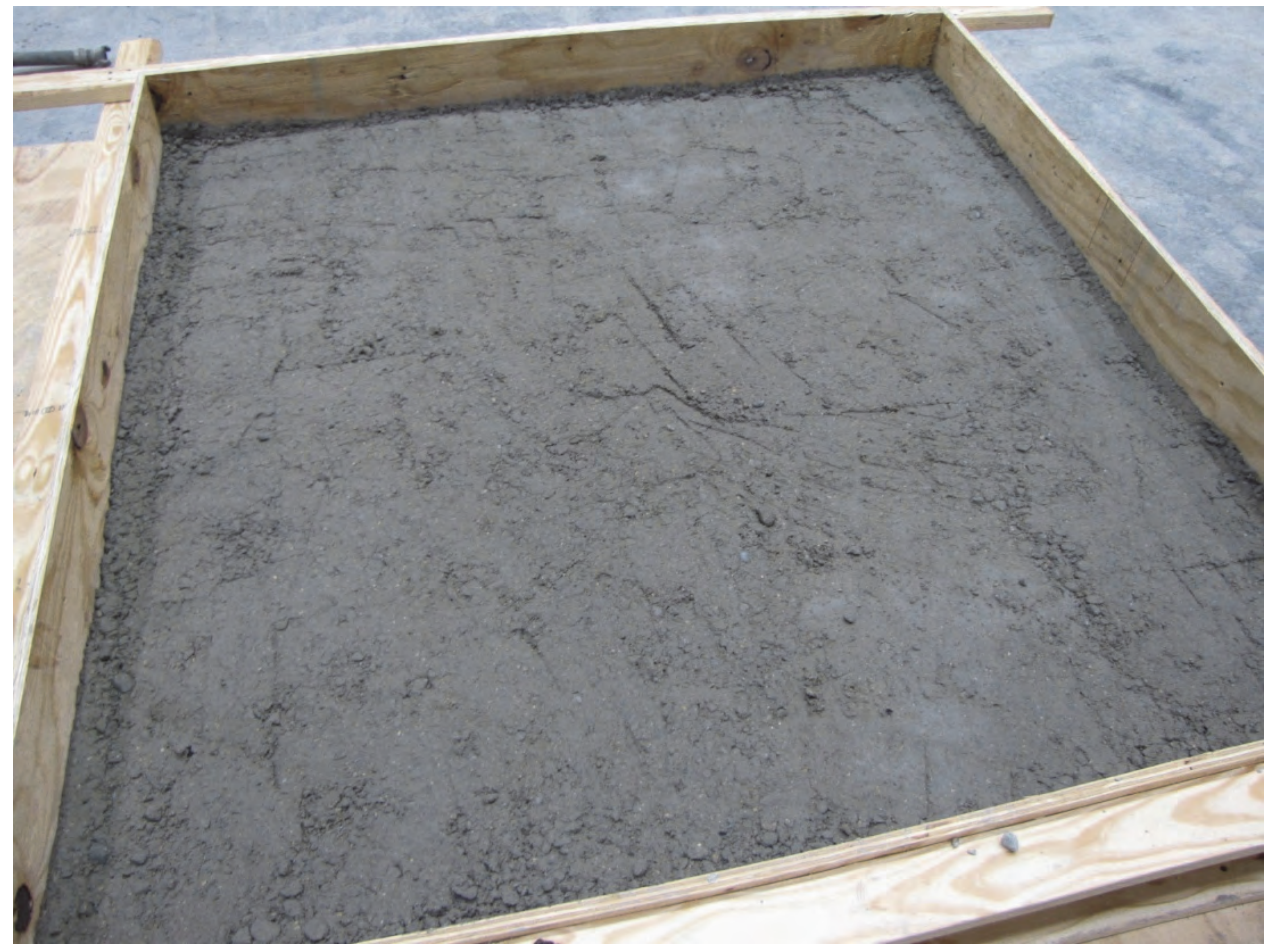

Figure B4. Finished surface of first RCC lift. 


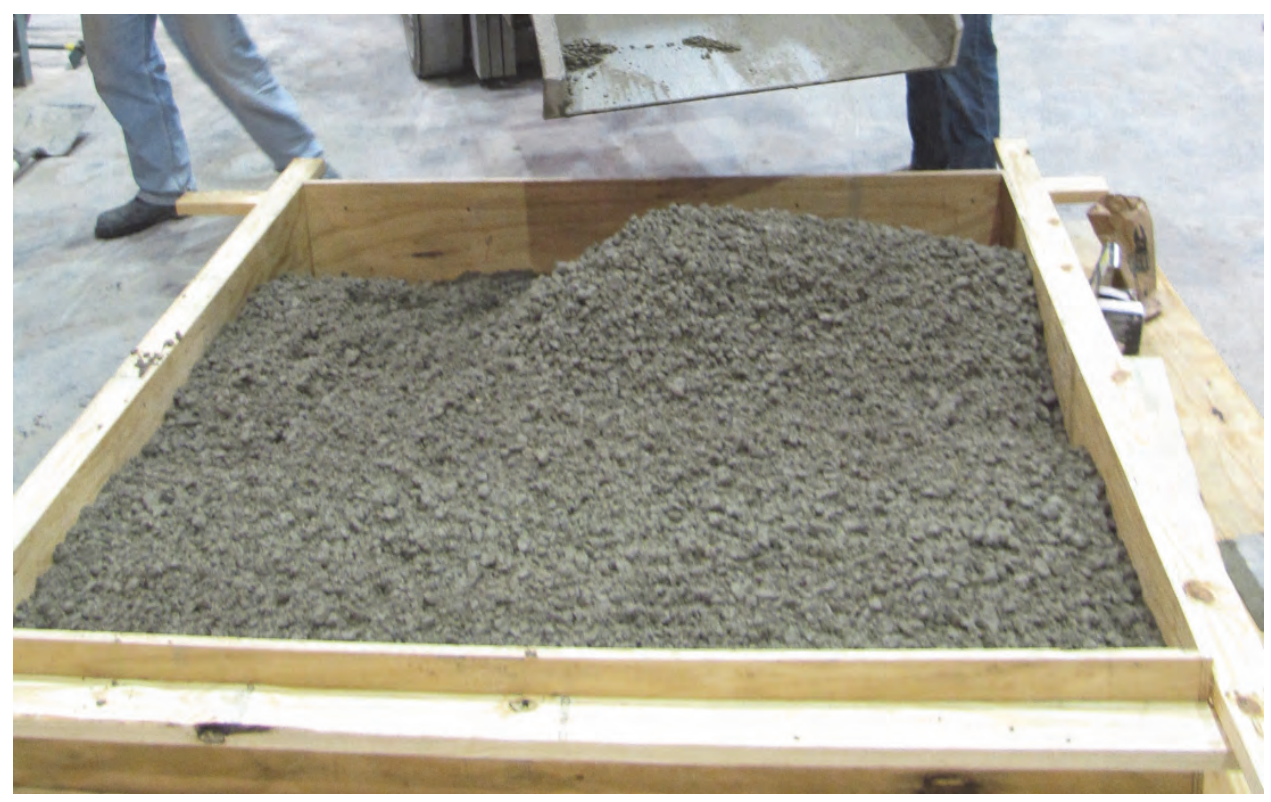

Figure B5. Second lift of concrete in forms prior to leveling and compaction.

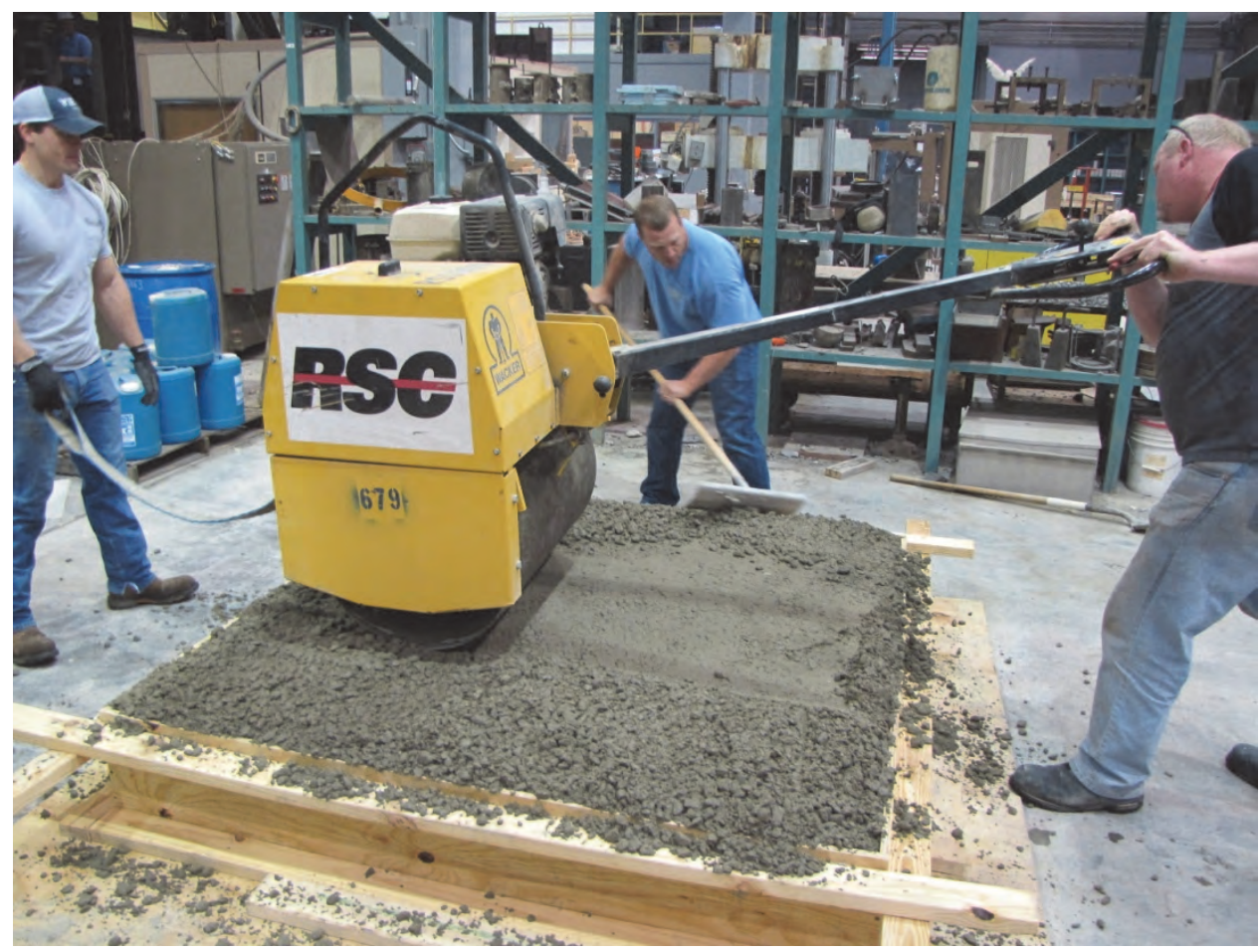

Figure B6. Second lift of concrete being roller compacted. 


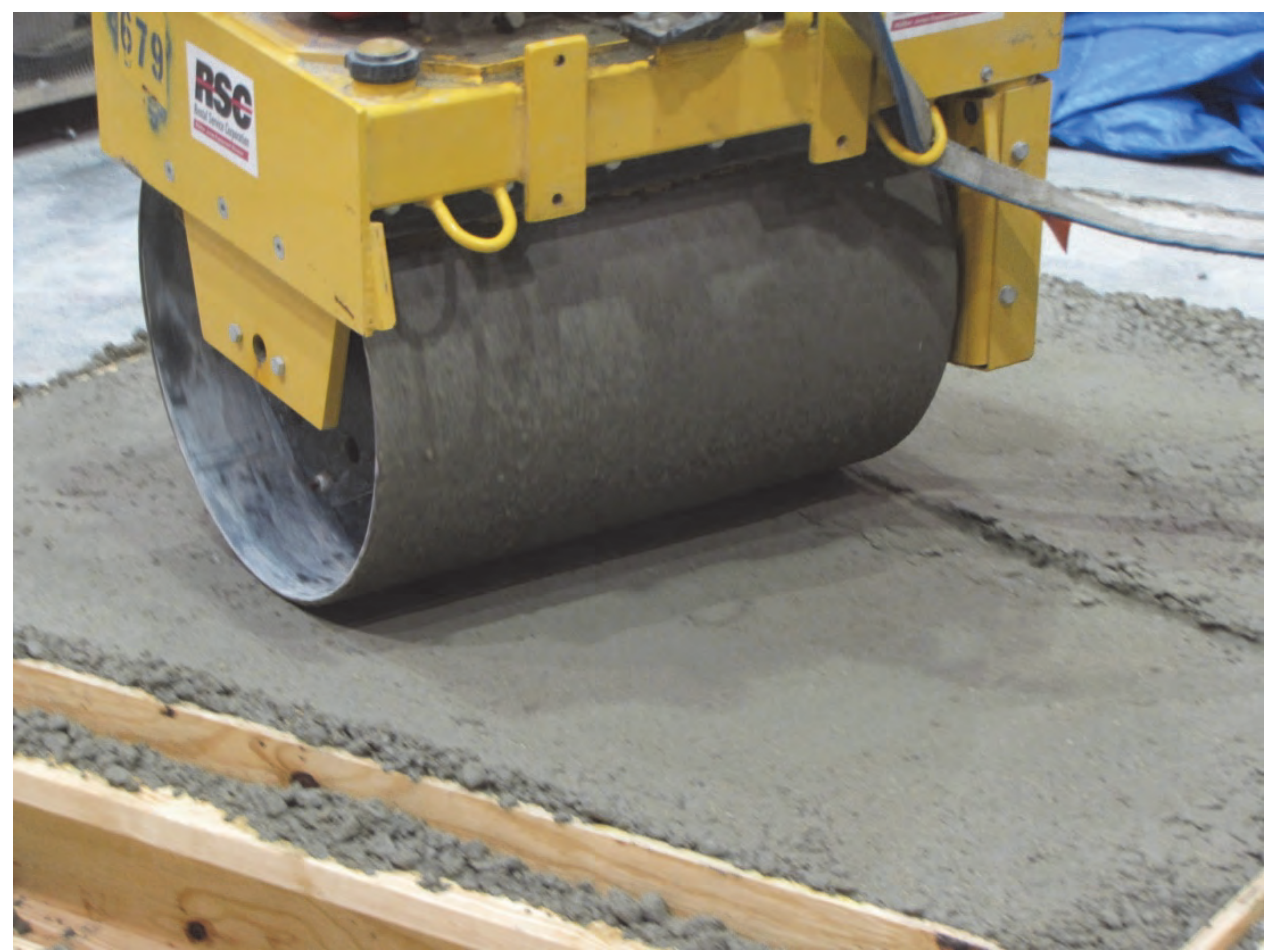

Figure B7. Close image of roller applying smooth surface.

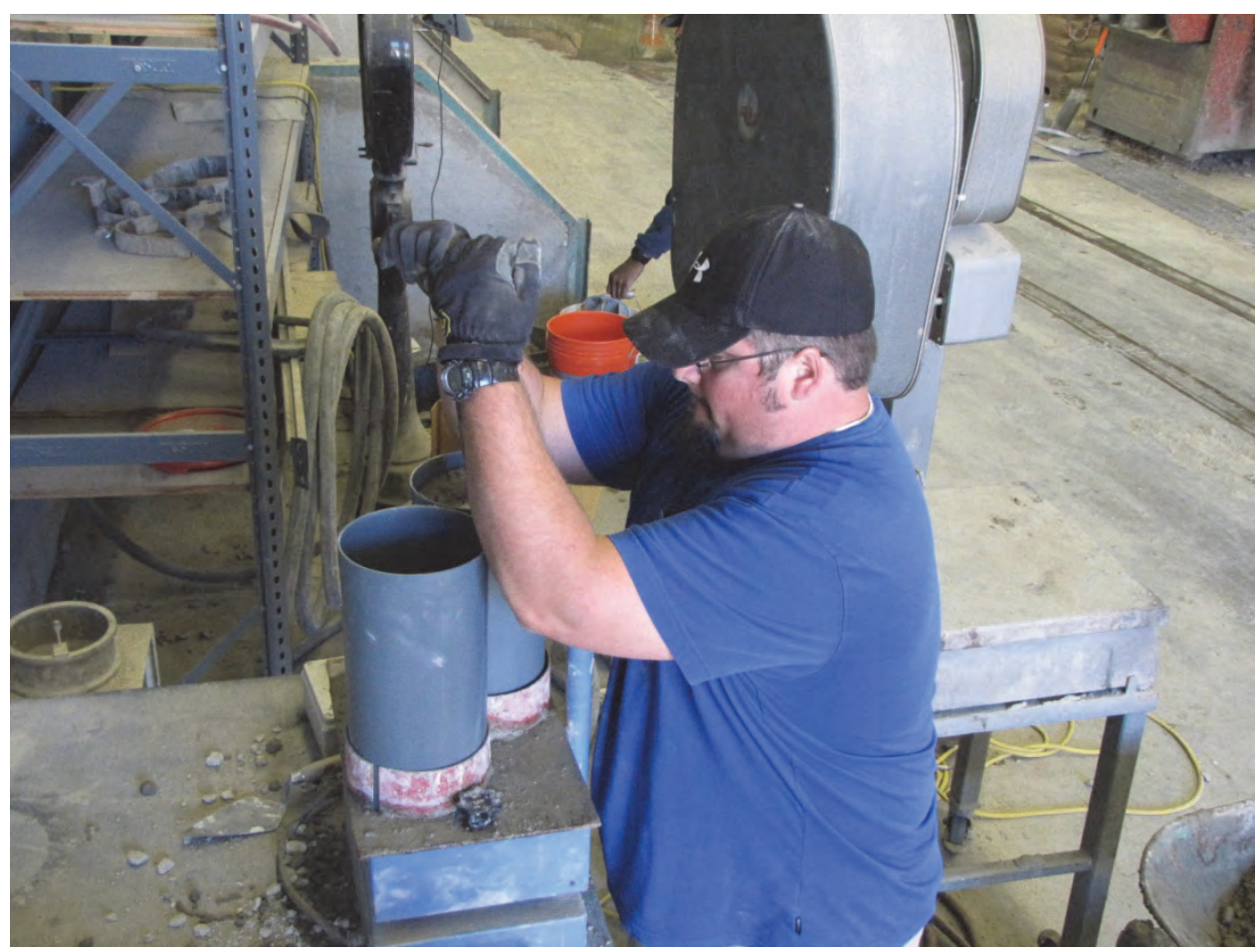

Figure B8. Cylinder being cast using the Vebe vibrating table. 


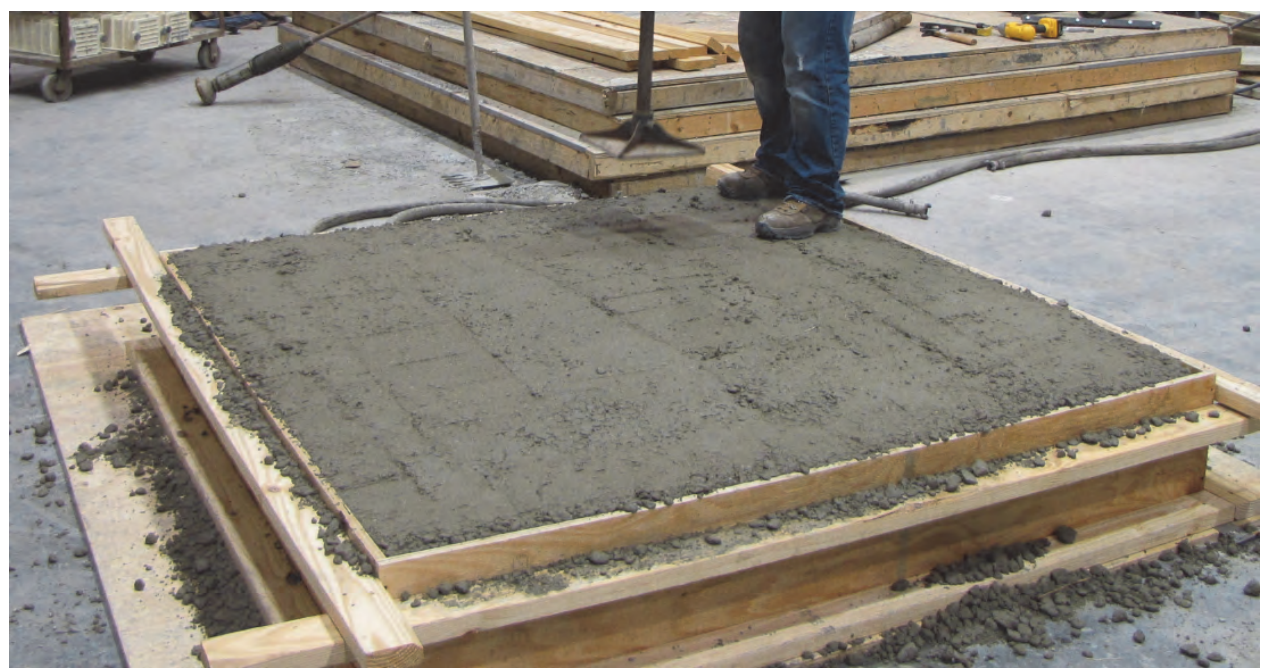

Figure B9. Final surface finish being applied via hand tamps.

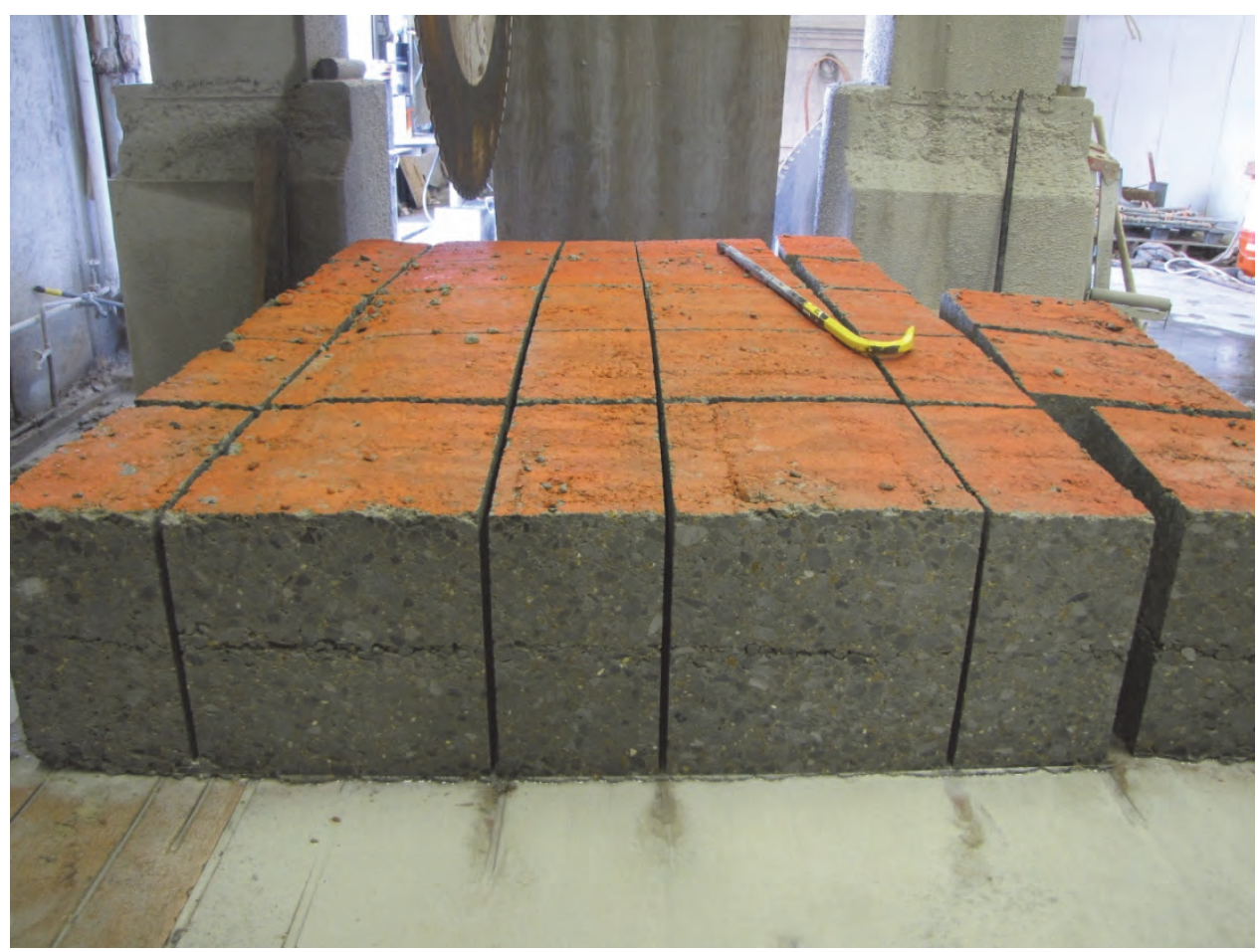

Figure B10. Test slab being cut into specimens for shear testing and coring. 


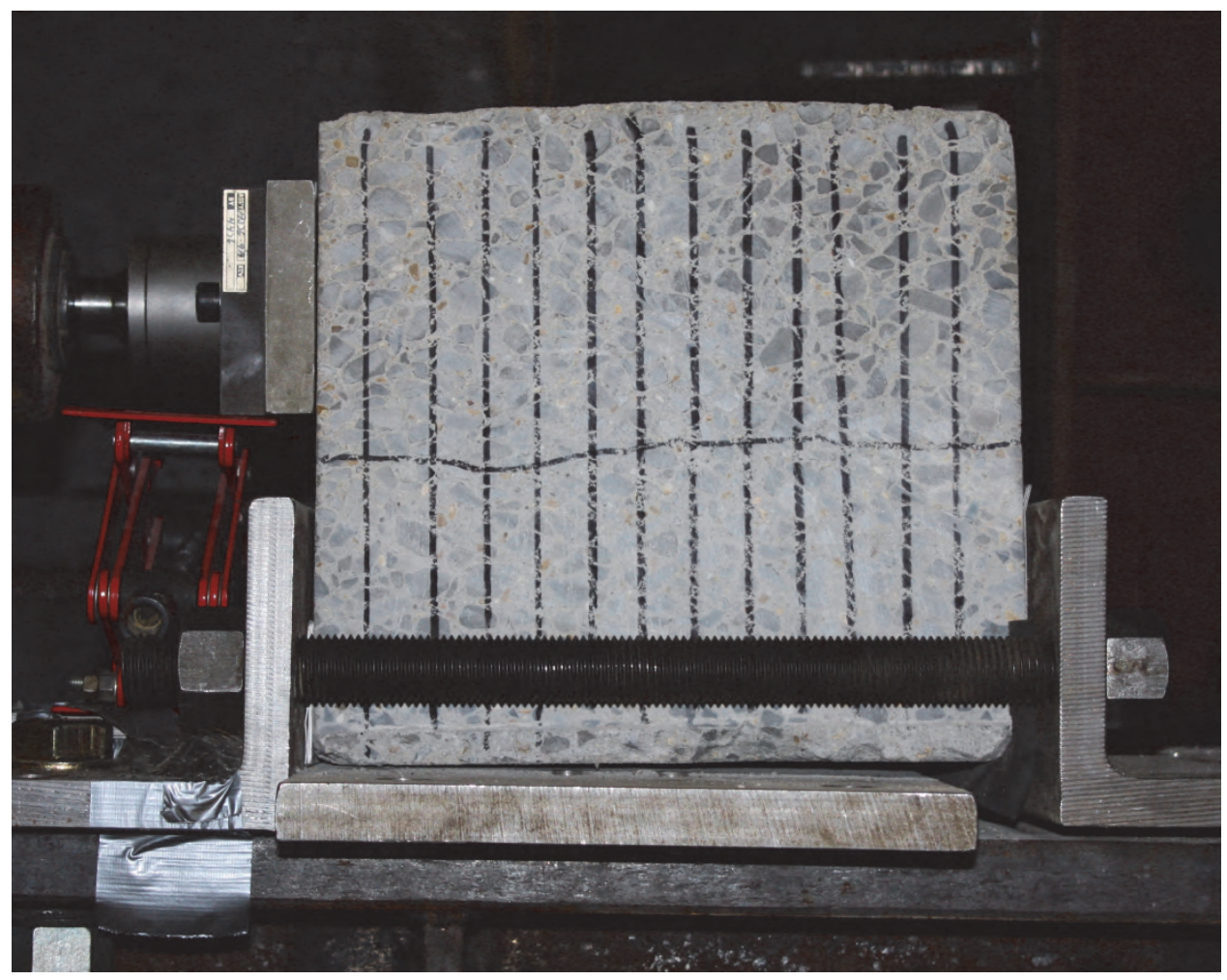

Figure B11. Shear block being tested in loading frame. 


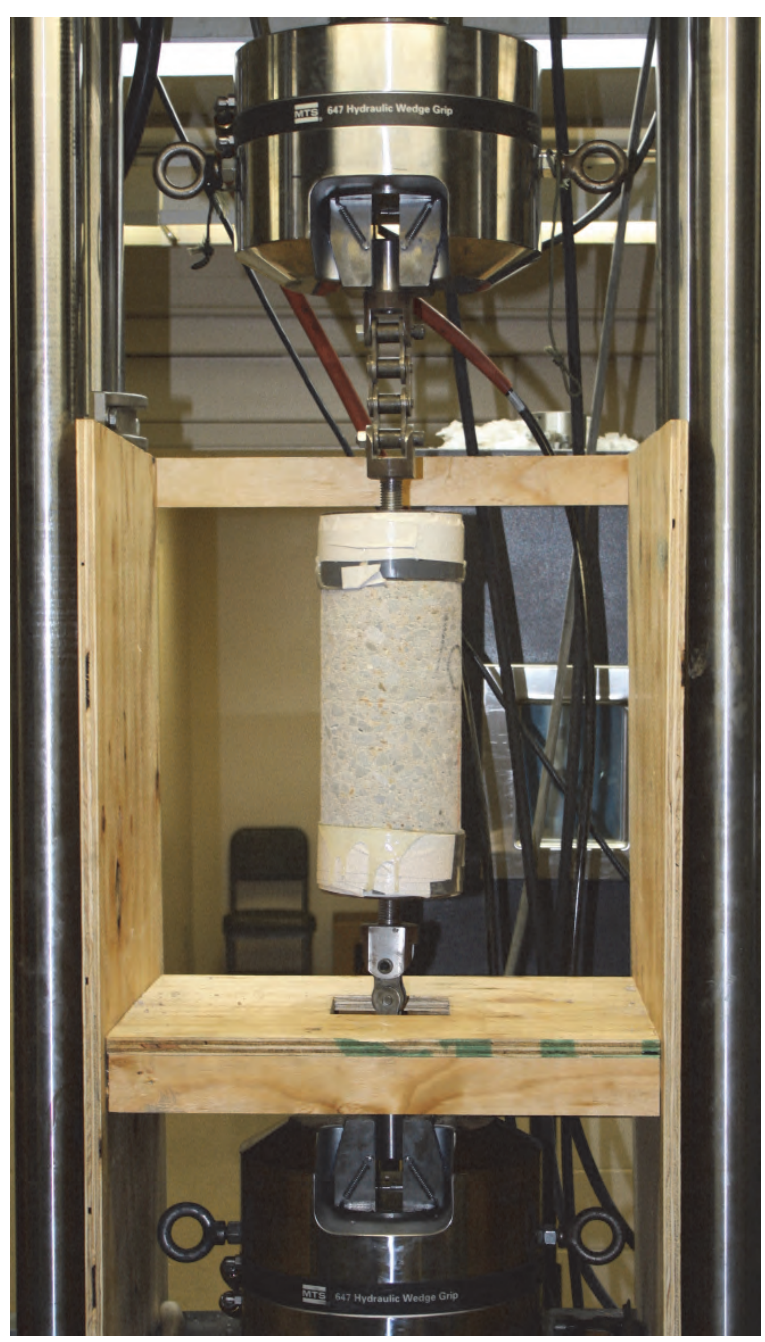

Figure B12. Concrete core in tension test machine.

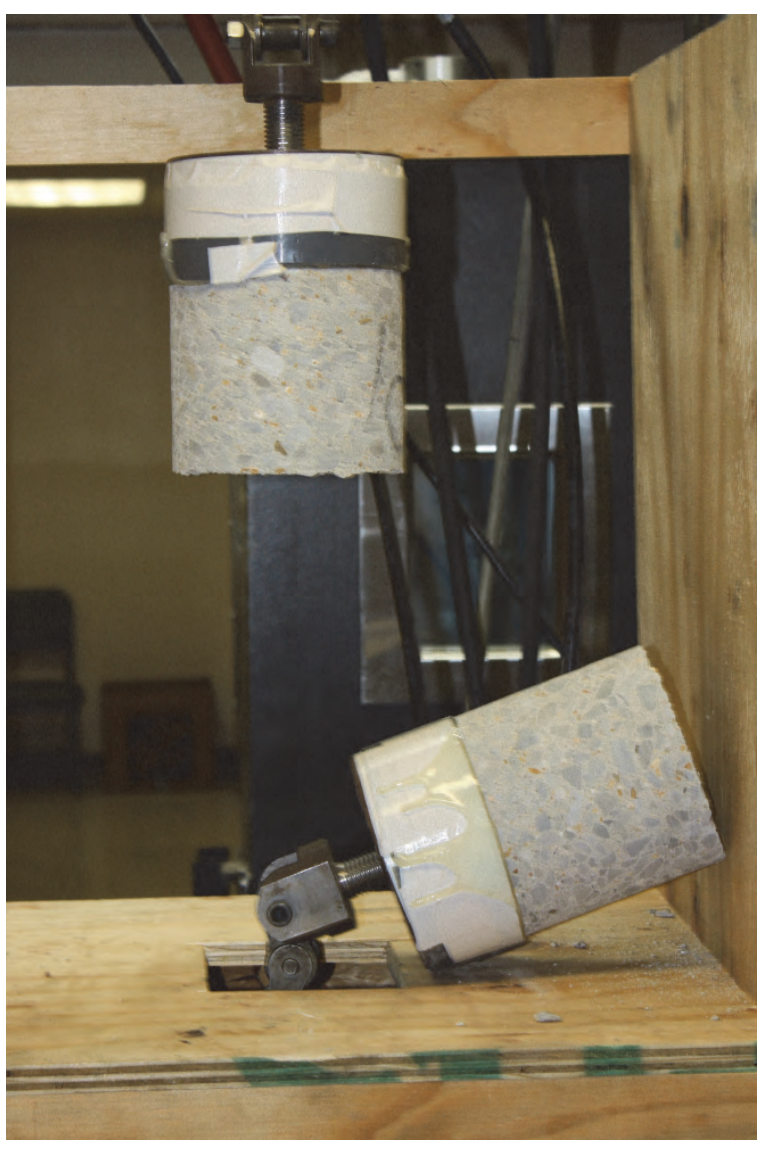

Figure B13. Concrete core after tension test was completed. 


\section{Appendix C: Investigation of Methods for Spreading Dry Cement Powder}

Concrete Topping Spreaders:

The NRCS Construction Specification 36 describes several methods for enhancing lift-joint bond. While much past practice is based on the belief that application of some type of bonding material improves the bond strength of lift joints, the information is not definitive as to which bonding methods are best, or whether any bonding material is actually needed. This determination can vary somewhat depending upon whether the angle of friction, cohesion, tensile strength, or permeability of the lift joint is the primary variable under evaluation. Since the addition of any bonding material to a lift joint adds cost to the construction, the NRCS desires to further examine the need for lift-joint treatment, and to examine new, potentially less expensive methods of application of lift-joint treatment materials.

Research conducted at ERDC has shown when a second RCC lift is placed after $4 \mathrm{hr}$ has passed that some form of lift joint treatment should be applied. The problem that is occurring is when $4 \mathrm{hr}$ time has passed, the cement paste from the bottom layer has set, and there is not enough available cement paste in the top layer to effectively bond the two lifts together at the joint interface. There are many different methods and materials that can be applied to create a stronger bond between RCC lifts. The most straightforward method and material is applying Portland cement paste to the surface of the bottom lift prior to the placement of the top lift. The following review will illustrate some of the methods and equipment that are currently being used in the industry to spread different cementitious materials and concrete toppers on the surface of concrete structures.

There are some special cases in concrete in which dyes, hardeners or other types of treatments (or toppings) are applied to the surface. Traditionally concrete surface treatments have been applied by hand. Buckets and scoops were used to spread the surface treatments that were then smoothed into the surface of the concrete with a trowel. This method is still used for small applications with some minor innovations. One of these innovations is a 
small, wheeled hopper rigged with a small uniform opening that can be pushed by one person that releases a small amount of surface treatment. Cost of this machine is approximately $\$ 1,000$.

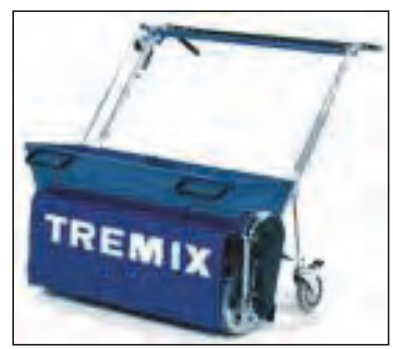

Figure C1. Man-powered topping spreader: Designed by Tremix.

Advanced, more efficient methods have been created to apply concrete surface treatments using equipment specifically designed to spread concrete toppings. One type is commonly called a "spreader bridge." The spreader bridge spans a single concrete slab and is manually pushed along the length of the slab. A powered bucketfull of surface treatment moves back and forth down the bridge spreading a thin layer of treatment. This piece of equipment can cost $\$ 3,000$ to $\$ 5,000$ depending on the length of the span, and requires no technical training to use. A picture of the spreader bridge can be found below.

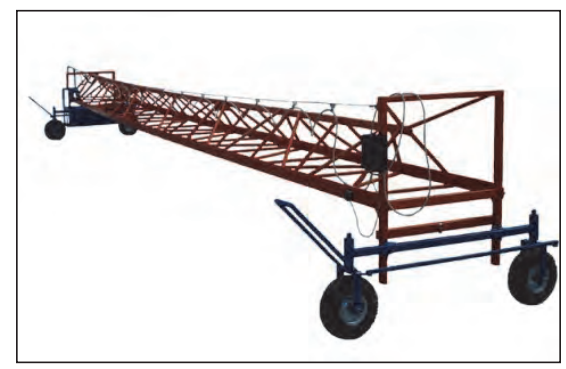

Figure C2. Manually pushed spreader bridge: Model designed by Alexey Gerasimchuck.

A mechanically operated and driven concrete topping spreader has been designed for large applications and fast-paced projects. This type of spreader can maneuver quickly around the surface intended for application and quickly spread a uniform layer of topping. The machine operates by approaching the edge of the concrete where it then levels itself with four hydraulic arms. Other hydraulic arms extend the spreader over the concrete surface and apply the treatment. A picture of this type of spreader can be seen below. 

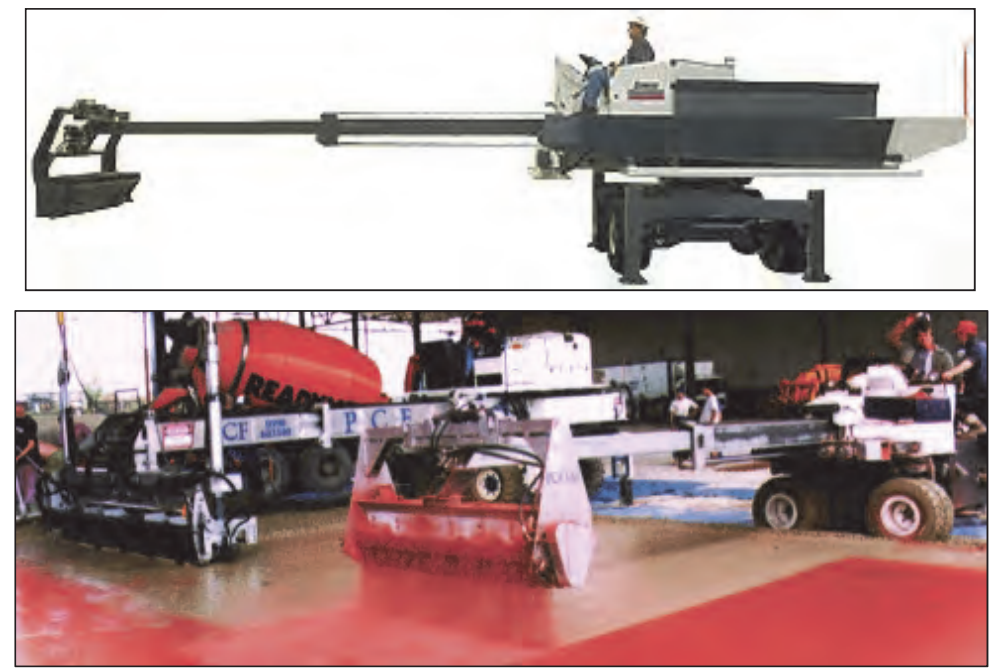

Figure C3. Mechanically operated spreader: Designed by Somero (Model STS-132 Somero Spreader).

Soil-Stabilization Spreaders:

The most common application for spreading cementitious material over large surfaces is found in soil stabilization. The equipment used in spreading soil stabilizers can be applicable to joint bonding materials for RCC. The majority of the equipment used for spreading soil stabilization operates the same way. Cementitious/ stabilization materials are placed in a hopper and are uniformly dispensed through an opening onto the surface of application. The size of equipment typically ranges from tractorpulled to vehicle mounted, depending on the surface area of application. The pictures below show the different types of cement spreaders for foil stabilization, starting from small scale to large scale.

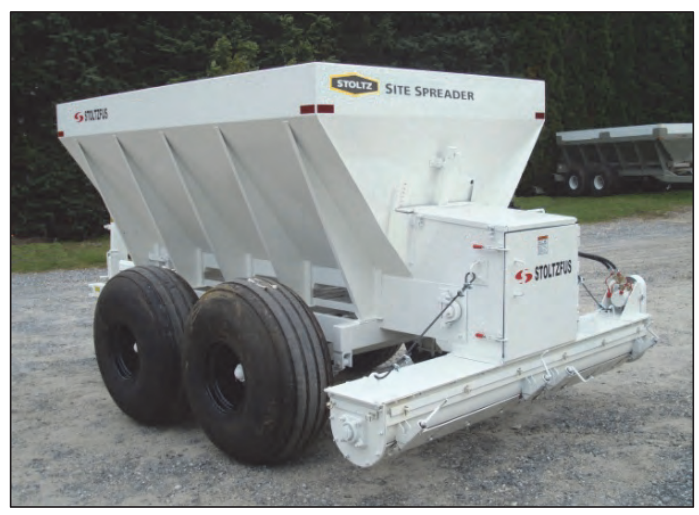

Figure C4. Tractor pulled cement spreader: Designed by Stoltz. 


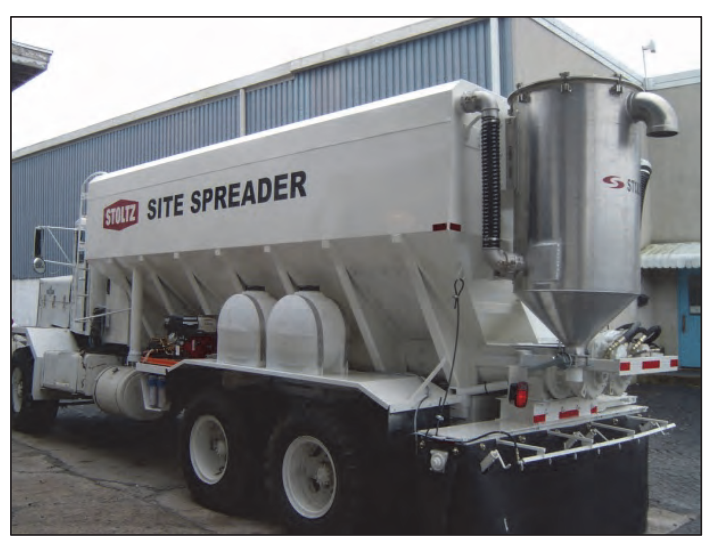

Figure C5. Operated vehicle cement spreader: Designed by Stoltz.

More Cost Economical Means for Spreading:

The machinery previously mentioned can reduce labor costs as well as construction times, but the initial upfront cost may not be feasible for all projects. The agricultural industry has some applicable equipment that is less expensive. There are a wide range of machines and devices that could be used to spread cementitious materials onto a concrete surface. The method with which the agricultural products spread materials can create large amounts of dust and waste, but will spread an even layer of material on the applied surface. The following pictures show a range of products that could be used to spread concrete toppings for a broad scope of applications.

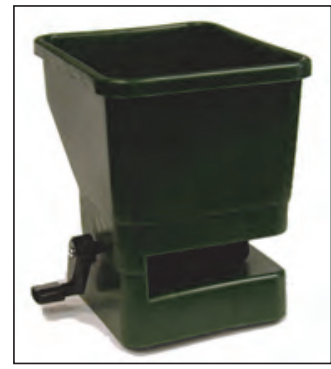

Figure C6. Hand crank fertilizer spreader: Generic. 


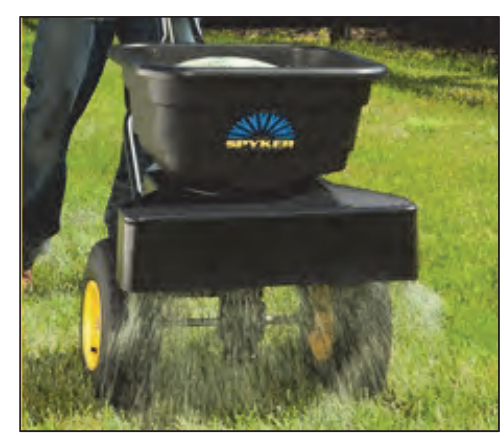

Figure C7. Manually pushed fertilizer spreader: Designed by Spyker.

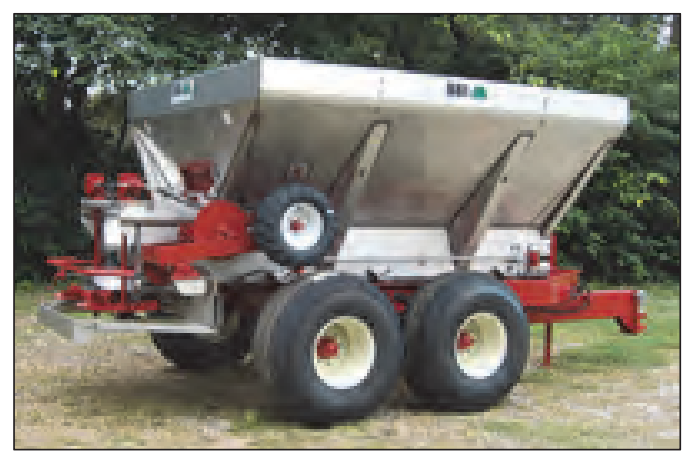

Figure C8. Tractor-pulled lime/fertilizer spreader: Designed by Liberty Mechanical (Model Power Fertilizer Lime Spreader OOLTY).

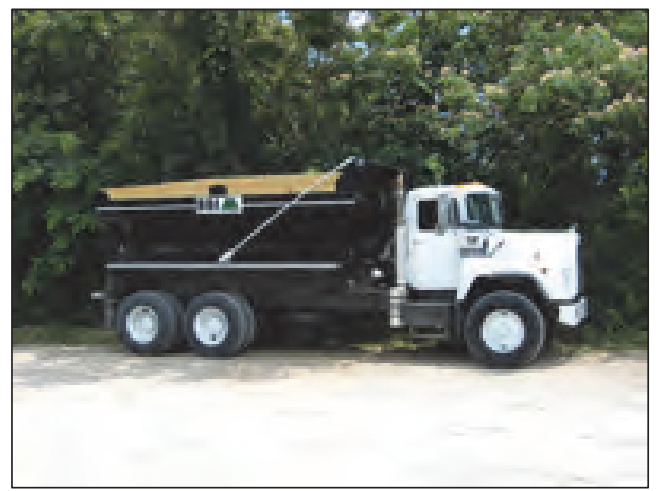

Figure C9. Truck-mounted aggregate spreader: Designed by BBI (Model RockBody OORB).

In most cases the greatest amount of bond strength comes from the friction force between the two layers. In this specific case, the normal loads are extremely low so friction forces are going to play a minimal role. What if the surface of the RCC could be finished in a way where an interlock between two layers could exist. For example, finish the bottom layer using a "sheep'sfoot" roller compactor so a checker pattern of indentions is created so when 
the next layer is placed, the indentions can be filled with fresh RCC forming an interlock of layers. On a smaller scale, the RCC bottom layer could be finished with hard rake (like in transportation construction) creating a surface with $1 / 4$ inch by $1 / 2$ parallel grooves where the paste from the next layer can seep in and form an interlock. 


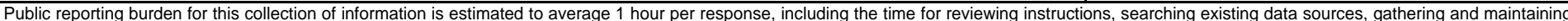

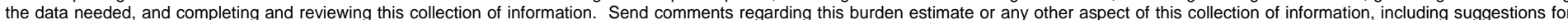

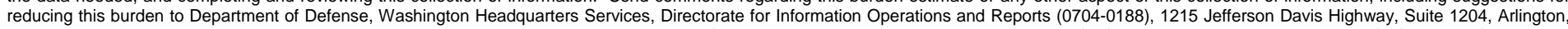

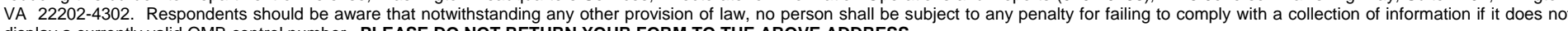
display a currently valid OMB control number. PLEASE DO NOT RETURN YOUR FORM TO THE ABOVE ADDRESS.

\begin{tabular}{l|c}
$\begin{array}{l}\text { 1. REPORT DATE (DD-MM-YYYY) } \\
\text { April } 2013\end{array}$ & $\begin{array}{c}\text { 2. REPORT TYPE } \\
\text { Final report }\end{array}$ \\
\hline
\end{tabular}

\section{TITLE AND SUBTITLE}

Investigation of Lift Bonding for Roller-Compacted Concrete with Low Normal Loads at Variable Placement Times

3. DATES COVERED (From - To)

$10 / 10-10 / 12$

5a. CONTRACT NUMBER

IA 67-7482-9-494

5b. GRANT NUMBER

5c. PROGRAM ELEMENT NUMBER

5d. PROJECT NUMBER

5e. TASK NUMBER

5f. WORK UNIT NUMBER

8. PERFORMING ORGANIZATION REPORT NUMBER

ERDC/GSL TR-13-7

U.S. Army Engineer Research and Development Center

Geotechnical and Structures Laboratory

3909 Halls Ferry Road

Vicksburg, MS 39180-6199

9. SPONSORING I MONITORING AGENCY NAME(S) AND ADDRESS(ES)

Headquarters, U.S. Army Corps of Engineers

Washington DC 20314-5000

Brett A. Williams, Brian H. Green, Rudolph A. Andreatta, Jason A. Morson,

M. Kevin Taylor, Kirk E. Walker, Dan E. Wilson, and William S. Hart

10. SPONSOR/MONITOR'S ACRONYM(S)

Natural Resource Conservation

Service (NRCS)

11. SPONSOR/MONITOR'S REPORT NUMBER(S)

12. DISTRIBUTION I AVAILABILITY STATEMENT

Approved for public release; distribution is unlimited.

\section{SUPPLEMENTARY NOTES}

\section{ABSTRACT}

A problem arises when roller-compacted concrete (RCC) is placed in lifts where the normal loads at the lift-joint interface are relatively low. A study was conducted to investigate the effects of lapses of time between lifts on shear, tensile, and bond strengths of an RCC structure. Three test sections were constructed, each including two 6-in.-thick lifts, with the second lift placed at either 4 , 13 , or 24 hr after the first lift was finished. Results of the study showed that if the second lift is placed within four hours of the first, the overall strength of the joint bond is increased. If the second lift is placed within $13 \mathrm{hr}$ of the first, the strength of the joint bond varies between increased and decreased strength throughout the surface area of the joint indicating signs of differential set times over the surface of the first lift. When the second lift is placed after $24 \mathrm{hr}$, the overall strength of the bond is decreased. These findings resulted from the execution of four different shear tests on each test section, where each shear test uniquely quantified the bond strength of the joint interface. The most adequate test method to quantify the shear strength of the bond was found to be the procedure in ASTM D 5607-08.

\begin{tabular}{lll}
\hline 15. SUBJECT TERMS & Shear strength & Cement spreader \\
Roller-Compacted Concrete & Tensile strength & \\
RCC & Lift joint &
\end{tabular}

16. SECURITY CLASSIFICATION OF:

\begin{tabular}{|l|l|l|}
\hline a. REPORT & b. ABSTRACT & c. THIS PAGE \\
UNCLASSIFIED & UNCLASSIFIED & UNCLASSIFIED \\
\hline
\end{tabular}

\begin{tabular}{|c|c|}
\hline $\begin{array}{c}\text { 17. LIMITATION } \\
\text { OF ABSTRACT }\end{array}$ & $\begin{array}{c}\text { 18. NUMBER } \\
\text { OF PAGES }\end{array}$ \\
\cline { 3 - 3 } & 47 \\
\hline
\end{tabular}

19a. NAME OF RESPONSIBLE PERSON Brett A. WIIliams

19b. TELEPHONE NUMBER (include area code) 601-634-3660 